\title{
Bibliography of Reports
}

Resulting From

U.S. Geological Survey

Participation in the

United States Technical

Assistance Program, 1940-65

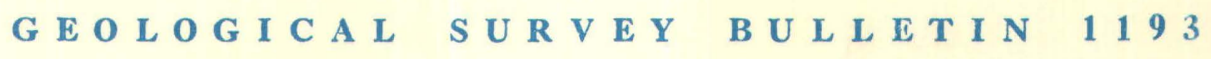

Prepared under the auspices of the Agency for International Development of the United States Department of State

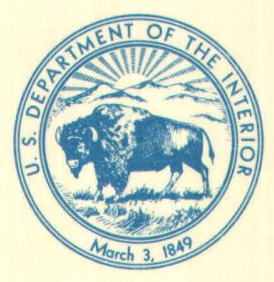





\section{Bibliography of Reports}

Resulting From

U.S. Geological Survey

Participation in the

United States Technical

Assistance Program, 1940-65 By JO ANN HEATH

G E O L O G I C A L S U R V E Y B U L L E T I N 1193

Prepared under the auspices of the Agency for International Development of the United States Department of State

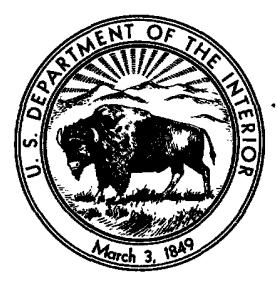


UNITED STATES DEPARTMENT OF THE INTERIOR

STEWART L. UDALL, Secretary

\author{
GEOLOGICAL SURVEY \\ William T. Pecora, Director
}

REPRINTED

1966 


\section{FOREWORD}

The bibliography here presented includes all reports and maps published or otherwise released to the public between 1940 and 1965 as a result of cooperative work carried on by scientists of the U.S. Geological Survey and its counterpart agencies abroad under the technical assistance program of the Agency for International Development of the U.S. Department of State. This bibliography is a measure of the wide variety of geological investigation and mapping undertaken in that program. The published results, however, represent but a fraction of the joint projects undertaken in this program of demonstration and training for the benefit of counterpart scientists and technicians. Papers published locally under the sole authorship of counterpart personnel are not included.

During the past quarter of a century, the U.S. Geological Survey's program in foreign countries has passed from cooperative investigations of critical or strategic mineral deposits and studies intended for immediate industrial stimulation in the developing countries, carried out at the request of host governments, to systematic, countrywide, long-range programs aimed at the assessment of national water and mineral resources, and involving training of scientific and administrative staffs in these countries.

The Geological Survey's activities are now trending more heavily to advice, guidance, and demonstration, in cooperation with counterpart institutions abroad.

In this bibliography, reports are listed chronologically under each country; author and subject indexes are included. Many of the papers have been published by the U.S. Geological Survey or its counterpart organization in the country involved; others have been published in scientific and trade journals throughout the world.

\section{George L. Schoechle}




.




\section{CONTENTS}

Page

Foreword _...

Bibliography of reports... 1

General _............... 1

Afghanistan

Argentina _. . . . .

Bolivia _...

Brazil _._.

British Guiana. . . . . . 10

Central America

Chile

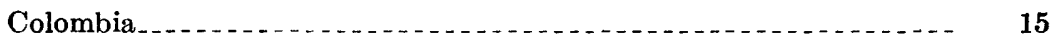

Costa Rica . . . . . 15

Cuba

Dominican Republic _.

Ecuador

Egypt_...

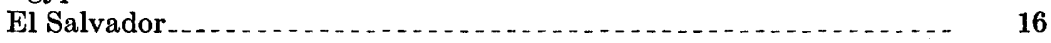

Ghana_

Haiti

India $\ldots \ldots \ldots \ldots$

Indonesia $\ldots \ldots \ldots \ldots \ldots \ldots$

Iran _.

Israel _....

Jamaica _. $\ldots \ldots \ldots \ldots \ldots$

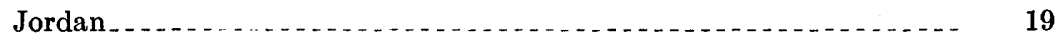

Kenya _ _ $\ldots \ldots \ldots \ldots \ldots$

Korea _.. $\ldots \ldots \ldots \ldots \ldots \ldots \ldots$

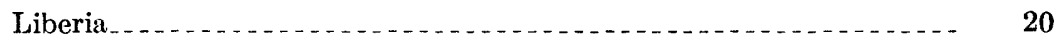

Libya _.

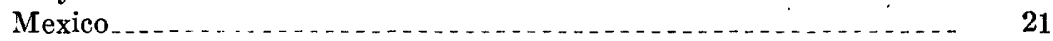

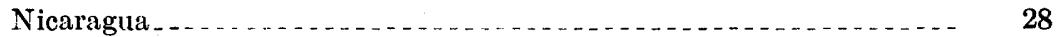

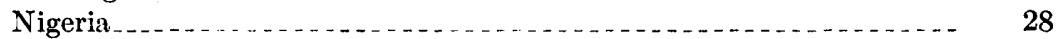

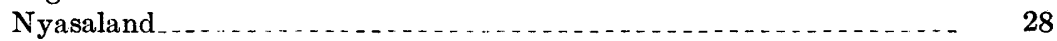

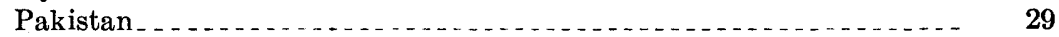

Panama ...

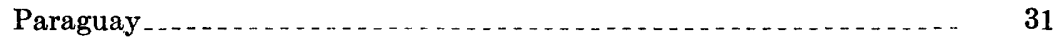

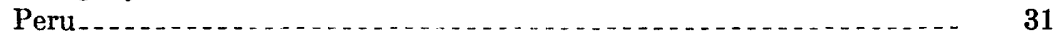

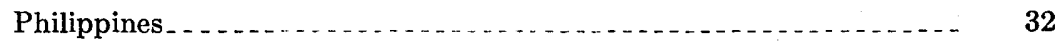

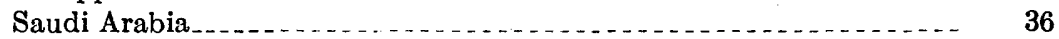

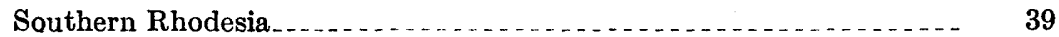

Sudan _...

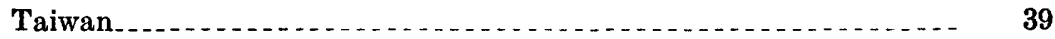


Bibliography of reports-Continued Page

Thailand ... 39

Tunisia

Turkey

Uruguay _. . . 40

Venezuela $\ldots \ldots \ldots$.

West Indies...... 41

Indexes . . .

Author index

Subject index 


\title{
BIBLIOGRAPHY OF REPORTS RESULTING FROM U.S. GEOLOGICAL SURVEY PARTICIPATION IN THE UNITED STATES TECHNICAL ASSISTANGE PROGRAM, 1940-65
}

\author{
By Jo Ann Heath
}

Ref. No.

\section{GENERAL}

1 Foreign work by the Geological Survey, U.S. Department of Interior [abs.], by J. V. N. Dorr 2d: Econ. Geology, v. 39, no. 1, p. 90, 1944.

2 The U.S. Geological Survey in other American Republics, by W. D. Johnston, Jr.: U.S. Dept. State, Record, v. 3, no. 2, p. 8-14, 1947; Washington Acad. Sci. Jour., v. 37, no. 10, p. 376, 1947.

3 U.S. Geological Survey's foreign technical assistance program 1940-1952 [abs.], by W. D. Johnston, Jr.: Geol. Soc. America Bull., v. 63, no. 12, pt. 2, p. 1268, 1952.

4 Introduction, by J. V. N. Dorr 2d, to paper entitled Role of geologists in the development of Labrador-Quebec iron ore district, by J. K. Gustafson and A. B. Moss: Engenharia, Mineração e Metalurgia, v. 18, no. 107, p. 237, 1953.

5 The basis for an operating organization, by T. E. Eakin: India, Central Board Geophysics, Ground Water Resources Comm., Symposium Ground Water, Proc., no. 4, p. 372-379, 1955.

6 The Geological Survey's training program for geologists from less developed countries, by D. A. Andrews, G. L. Schoechle, and G. W. Brown: Jour. Geol. Educ., v. 11, no. 4, p. 113-118, 1963.

7 In-service and university training of geologists and mineral engineers, by G. L. Schoechle and H. A. Meyerhoff: United Nations Conf. Application Sci. and Tech. Benefit Less Developed Areas, Geneva 1963, v. 2, p. 90$105,1963$.

8 The role of national geological surveys in mineral resources development, by W. D. Johnston, Jr.: United Nations Conf. Application Sci. and Tech. Benefit Less Developed Areas, Geneva 1963, v. 2, p. 18-22, 1963.

\section{AFGHANISTAN}

9 Stream gaging problems in Afghanistan, by I. A. Heckmiller: Internat. Assoc. Sci. Hydrology Bull., 6th year, no. 3, p. 35-37, 1961.

10 Compilation of hydrologic data, Helmand River valley, Afghanistan, through September 1960, by R. H. Brigham: U.S. Geol. Survey open-file report, 236 p., 1964.

\section{ARGENTINA}

11 Tungsten investigations in the Republic of Argentina, 1942-43, by W. C. Smith and E. M. Gonzáles: U.S. Geol. Survey Bull. 954-A, p. 1-37, pls. 1-17, 1947. 
Ret. No.

\section{BOIIVIA}

12 Preliminary report on the geology of the Upper La Paz Valley, Bolivia, by Ernest Dobrovolny: U.S. Geol. Survey open-file report, 32 p., 1 pl., 6 figs., 1955.

13 Geología del Valle Superior de La Paz, Bolivia, by Ernest Dobrovolny: La Paz, Bolivia, Bol. Municipal (spec. issue), 60 p., 15 illus., 1956.

14 Parque Central, Santa Barbara, Villa Pabon landslide area, La Paz, Bolivia, by Ernest Dobrovolny: Geol. Soc. America Bull., v. 71, no. 12, p. 2033, 1960.

15 Geología del Valle de La Paz, by Ernest Dobrovolny, with a section on Aguas subterráneas, by H. E. Thomas: Bolivia, Dept. Nac. Geología Bol. 3 (spec. issue), 153 p., 8 maps, 13 figs., 1962.

\section{BRAZII}

16 The beryl-tantalite-cassiterite pegmatites of Paraíba and Rio Grande do Norte, northeastern Brazil, by S. C. de Almeida, W. D. Johnston, Jr., O. H. Leonardos, and E. P. Scorza: Econ. Geology, v. 39, no. 3, p. 206223, 1944; [in Portuguese] Engenharia, Mineração e Metalurgia, v. 7, no. 39 , p. 115-126, 34 figs., 1943.

17 Layered or banded chromite at Campo Formoso, Baía, Brazil, by W. D. Johnston, Jr., and H. Capper A. de Souza: Econ. Geology, v. 38, no. 4, p. 287-297, 1943.

18 Os recursos minerais do Brasil, by W. D. Johnston, Jr.: Engenharia, Mineração e Metalurgia, v. 7, no. 40, p. 179-180, 1943.

19 Tungstênio na Paraíba e Rio Grande do Norte, by W. D. Johnston, Jr., and F. M. de Vasconcelos: Engenharia, Mineração e Metalurgia, v. 7, no. 41, p. 247-260, 1943; Brazil, Div. Fomento Produção Mineral Avulso 52,37 p., 1944.

20 A apatita de São Tome, Município de Alagoas do Monteiro, Estado da Paraíba, by W. D. Johnston, Jr.: Engenharia, Mineração e Metalurgia, v. 8 , no. 45 , p. $187-188,1944$.

21 Cristal de rocha em Cristalina, Estado de Goiás, by W. D. Johnston, Jr.: Brazil, Div. Fomento Produção Mineral Avulso 57, 28 p., 1944.

22 As minas de scheelita de Barra Verde, Barro Vermelho, Bodó e Cafuca, Rio Grande do Norte, by W. D. Johnston, Jr.: Engenharia, Mineração e Metalurgia, v. 8, no. 44, p. 95-100, 1944.

23 Nickel-silicate and associated nickel-cobalt-manganese oxide deposits near São José do Tocantins, Goiáz, Brazil, by W. T. Pecora: U.S. Geol. Survey Bull. 935-E, p. 247-305, pls. 44-50, figs. 12-14, 1944; [in Portuguese] in collaboration with A. L. M. Barbosa, Brazil, Div. Fomento Produção Mineral Bol. 64, 69 p., 1944.

24 Recursos minerais do Brasil; o surto de mineração no Nordeste, by W. D. Johnston, Jr.: Rev. Química Industrial, v. 13, no. 151, p. 19-21, 1944.

25 O atual estado do "age work" no Brasil, by W. D. Johnston, Jr.: Engenharia, Mineração e Metalurgia, v. 9, no. 52, p. 192, 1945.

26 Beryl-tantalite pegmatites of northeastern Brazil, by W. D. Johnston, Jr.: Geol. Soc. America Bull., v. 56, no. 11, p. 1015-1069, 1945; [in Portuguese] Brazil, Div. Fomento Produção Mineral Bol. 72, 85 p., 1945.

27 Brazilian scheelite [abs.], by W. D. Johnston, Jr., and F. M. de Vasconcelos: Mining Mag., v. 72, no. 6, p. 374-375, London, 1945.

28 Manganese and iron deposits of Morro do Urucum, Mato Grosso, Brazil, by J. V. N. Dorr 2d: U.S. Geol. Survey Bull. 946-A, p. 1-47, figs. 6-38, 
Ref. No.

1945; [in Portuguese] Brazil, Div. Fomento Produção Mineral Bol. 76, 76 p., 6 maps, 1946.

29 Mica; lavra do Bananal, Peçanha, Minas Gerais, by W. T. Pecora and A. L. M. Barbosa: Brazil, Div. Fomento Produção Mineral Avulso 67, 32 p., 1945.

30 Mica; lavra do Pequerí, Município de Bicas, Minas Gerais, Brasil, by M. R. Klepper, D. M. Larrabee, and A. L. M. Barbosa: Brazil, Div. Fomento Produção Mineral Avulso 69, 37 p., 1945.

31 Mica; lavra Viuva Valério, Município de Manhumirim, Minas Gerais, Brasil, by D. M. Larrabee and Resk Frayha: Brazil, Div. Fomento Produção Mineral Avulso 72, 25 p., 1 map, 1945.

32 Mica na Serra dos Lourenços, Peçanha, Minas Gerais, Brasil, by W. T. Pecora and A. L. M. Barbosa: Brazil, Div. Fomento Produção Mineral Avulso 68, 42 p., 1945.

33 Pegmatitos ambligonita-berilo tantalíferos do Ceará, Nordeste do Brasil, by W. D. Johnston, Jr.: Brazil, Div. Fomento Produção Mineral Avulso 66, 43 p., 1945.

34 Pegmatitos berilo-tantalíferos de Parelhas, Rio Grande do Norte, by W. D. Johnston, Jr.: Engenharia, Mineração e Metalurgia, v. 8, no. 46, p. 269-272, 1945.

35 Quartz crystal in Brazil [abs.], by W. D. Johnston, Jr., and R. D. Butler: Geol. Soc. America Bull., v. 56, no. 12, pt. 2, p. 1171, 1945; Econ. Geology, v. 40 , no. 8 , p. 595,1945 ; [in Portuguese] Brazil, Div. Fomento Produção Mineral Bol. 79, p. 139-141, 1945.

36 Scheelite in northeastern Brazil, by W. D. Johnston, Jr., and F. M. de Vasconcelos: Econ. Geology, v. 40, no. 1, p. 34-50, 1945.

37 Estanho (ouro, tantalita e diamantes), Território do Amaṕ́, by M. R. Klepper and Victor Dequech: Brazil, Div. Fomento Produção Mineral Bol. 79, p. 89-113, 1946.

38 Mica; Estado de Minas Gerais, Brasil, by M. R. Klepper and Resk Frayha: Brazil, Div. Fomento Produção Mineral Bol. 79, p. 123-125, 1946.

39 Quartz crystal in Brazil, by W. D. Johnston, Jr., and R. D. Butler: Geol. Soc. America Bull., v. 57, no. 7, p. 601-649, 1946.

40 Classification of the Gondwanic rocks of Paraná, Santa Catarina and Rio Grande do Sul, by Mackenzie Gordon, Jr.: Brazil, Div. Geologia e Mineralogia, Notas Prelim. e Estudos 38a, 20 p., 1947.

41 Mica-bearing pegmatites in Minas Gerais, Brazil, by M. R. Klepper, W. T. Pecora, and D. M. Larrabee: Washington Acad. Sci. Jour., v. 37, no. 10, p. $370-371,1947$.

42 Minério de manganês do Morro do Urucum, Mato Grosso, Brasil, by J. V. N. Dorr 2d: Rev. Brasileira de Química, Ano 12,v. 13, no. 136, p. 216-228; no. 137 , p. 274-284; no. 138 , p. 322-328, 1947.

43 Scorzalite and souzalite, two new phosphate minerals associated with brazilianite, Minas Gerais, Brazil [abs.], by W. T. Pecora and J. J. Fahey: Geol. Soc. America Bull., v. 58, no. 12, pt. 2, p. 1216-1217, 1947; [in Portuguese] Engenharia, Mineração e Metalurgia, v. 13, no. 73, p. 53-54, 1948.

44 Barite deposits of Camamú Bay, State of Bahia, Brazil, by A. J. Bodenlos: U.S. Geol. Survey Bull. 960-A, p. 1-34, 1948.

45 The magnesite deposits of Brazil, by A. J. Bodenlos: Engenharia, Mineração e Metalurgia, v. 13, no. 74, p. 136, 1948. 
Ref. No.

46 Preliminary report on manganese deposits in the Serra do Navio district, Territory of Amapá, Brazil, by J. V. N. Dorr 2d and P. W. Guild: U.S. Geol. Survey open-file report, 1948.

47 O surto de mineração do Brasil, by W. D. Johnston, Jr.: Rev. Química Industrial, v. 16, no. 169-170, p. 9-10, 23, 1948.

48 The Corrego Frio pegmatite, Minas Gerais; scorzalite and souzalite, two new phosphate minerals, by W. T. Pecora and J. J. Fahey: Am. Mineralogist, v. 34, no. 1-2, p. 83-93, 1949.

49 Manganese deposits of the Serra do Navio district, Territory of Amapá, Brazil, by J. V. N. Dorr 2d, C. F. Park, Jr., and Glycon de Paiva: U.S. Geol. Survey Bull. 964-A, 51 p., 4 pls., 1 fig., 1949; [in Portuguese] Brazil, Div. Fomento Produção Mineral Bol. 85, 80 p., 4 maps, 1950.

50 Notes on iron ores of central Minas Gerais, Brazil [abs.], by J. V. N. Dorr 2d and P. W. Guild: Econ. Geology, v. 44, no. 7, p. 636, 1949; Geol. Soc. America Bull., v. 60, no. 12, pt. 2, p. 1883, 1949.

51 A ocorrência de sulfetos nos minerais de manganês do Brasil, by J. V. N. Dorr 2d: Acad. Brasileira de Ciências Anais, v. 21, no. 4, p. 351-352, 1949.

52 Comentário do artigo "Contribuição à geologia da região Brasil-Bolivia," do Prof. Octavio Barbosa, by J. V. N. Dorr 2d: Engenharia, Mineração e Metalurgia, v. 14, no. 84, p. 148-150, 1950.

53 How much iron ore in Brazil? by J. V. N. Dorr 2d: Iron Age, v. 166, no. 7, p. 81-84; no. 8, p. 79-83, 1950.

54 The lazulite-scorzalite isomorphous series, by W. T. Pecora and J. J. Fahey: Am. Mineralogist, v. 35, no. 1-2, p. 1-18, 1950.

Magnesite deposits of central Ceará, Brazil, by A. J. Bodenlos: U.S. Geol. Survey Bull. 962-C, p. 121-153, pls. 26-31, figs. 6-8, 1950.

Mica deposits in Minas Gerais, Brazil, by W. T. Pecora, M. R. Klepper, D. M. Larrabee, A. L. M. Barbosa, and Resk Frayha: U.S. Geol. Survey Bull. 964-C, p. 205-305, pls. 14-17, figs. 6-38, 1950.

Ores and mining in the Itabira iron district, Brazil [abs.], by Gilbert Whitehead and J. V. N. Dorr 2d: Econ. Geology, v. 45, no. 4, p. 389-390, 1950.

Structure and mineralogy of the Golconda pegmatite, Minas Gerais, Brazil, by W. T. Pecora, George Switzer, A. L. M. Barbosa, and A. T. Myers: Am. Mineralogist, v. 35, no. 9-10, p. 889-901, 1950.

Iron and manganese ores of Brazil, by C. F. Park, Jr.: Japan Mining Geology, v. 1, no. 1, p. 27-28, 1951.

60 The iron ores of central Minas Gerais, Brazil, by J. V. N. Dorr 2d: Engenharia, Mineração e Metalurgia, v. 16, no. 92, p. 95-100, 1951.

Notes on the manganese ores of Brazil, by C. F. Park, Jr., J. V. N. Dorr 2d, P. W. Guild, and A. L. M. Barbosa: Econ. Geology, v. 46, no. 1, p. 1-22, 1951.

Iron deposits of the Congonhas district, Minas Gerais, Brazil [abs.], by P. W. Guild: Geol. Soc. America Bull., v. 63, no. 12, pt. 2, p. 1257, 1952.

Origin of the Brazilian iron ores, by J. V. N. Dorr 2d, P. W. Guild, and A. L. M. Barbosa: Internat. Geol. Cong., 19th, Algiers 1952, Symposium sur gisements fer du monde, v. 1, p. 286-298, 1952; [in Portuguese] Brazil, Div. Geologia e Mineralogia Bol. 144, p. 11-38, map, 1953.

Plantas triássicas do sul do Brasil, by Mackenzie Gordon, Jr., and R. W. Brown: Brazil, Div. Geologia e Mineralogia, Notas Prelim. e Estudos 54, 6 p., 1 pl., 1952. 
Ref. No.

65 Aplicação da análise microtectônica na solução de alguns problems geologicos, by Earl Ingerson: Engenharia, Mineração e Metalurgia, v. 18, no. 108 , p. $297-301$; v. 19 , no. 109 , p. 17-20, 1953.

Iron deposits of the Congonhas district, Minas Gerais, Brazil, by P. W. Guild: Econ. Geology, v. 48, no. 8, p. 639-676, 1953.

67 Moraesite, a new hydrous beryllium phosphate from Minas Gerais, Brazil, by M. L. Lindberg, W. T. Pecora, and A. L. M. Barbosa: Am. Mineralogist, v. 38, no. 11-12, p. 1126-1133, 1953.

68 Avelinoite, a new hydrous sodium ferric phosphate from Minas Gerais, Brazil, by M. L. Lindberg and W. T. Pecora: Science, v. 120, no. 3130, p. 1074-1075, 1954.

69 Contacto basal da Série de Minas na parte ocidental do Quadrilátero Ferrífero, Minas Gerais, Brasil, by G. A. Rynearson, J. B. Pomerene, and J. V. N. Dorr 2d: Brazil, Div. Geologia e Mineralogia Avulso 34, 18 p., 1 map, 1954.

70 A foreign geologist looks at Brazil's mineral future, by W. D. Johnston, Jr.: Acad. Brasileira de Ciências Anais, v. 26, no. 1, p. 87-100, 1954.

71 Geology of the iron deposits of the Congonhas district, Minas Gerais, Brazil, by P. W. Guild: Science, v. 119, no 3096, p. 616, 1954.

The iron deposits of the Congonhas district, Minas Gerais, Brazil-Comments on, by J. V. N. Dorr 2d: Econ. Geology, v. 49, no. 6, p. 659-662, 1954.

Magnesite deposits in the Serra das Éguas, Brumado, Bahia, Brazil, by A. J. Bodenlos: U.S. Geol. Survey Bull. 975-C, p. 87-170, pls. 12-18, figs. 8-19, 1954.

74 Tavorite and barbosalite, two new phosphate minerals from Minas Gerais, Brazil, by M. L. Lindberg and W. T. Pecora: Science, v. 119, no. 3099, p. 739, 1954; Am. Mineralogist, v. 40, no. 11-12, p. 952-966, 1955.

Alguns tipos de jazidas uraniferas, by M. G. White: Engenharia, Mineração e Metalurgia, v. 21, no. 125, p. 219-221, 1955.

Mineral deposits of Brazil, by W. D. Johnston, Jr.: Conf. Latin American Geology, Texas Univ., 1954, Proc., p. 83-99, 1955.

The manganese deposits of Minas Gerais, Brazil, by J. V. N. Dorr 2d, Arthur Horen, and I. S. Coelho: Internat. Geol. Cong., 20th, Mexico 1956, Symposium sobre Yacimientos Manganeso, v. 3, p. 279-346, 1956; [in Portuguese] Brazil, Div. Fomento Produção Mineral Bol. 105, 95 p., 6 figs. 5 illus., 1958.

78 O problema dos minérios de ferro Brasileiros visto por um geólogo, by J. V. N. Dorr 2d: Engenharia, Mineração e Metalurgia, v. 24, no. 144, p. 365-372, 1956.

Uranium in the Serra de Jacobina, State of Bahia, Brazil, by M. G. White: Internat. Conf. Peaceful Uses Atomic Energy, Geneva 1956, Proc., v. 6, p. 140-142, 1956.

Zinc and copper mineralization of the Vazante area, Minas Gerais, Brazil, by S. L. Moore: U.S. Geol. Survey open-file report, 23 p., 2 pls., 2 figs., 1956.

81 Geology and mineral resources of the Congonhas district, Minas Gerais, Brazil, by P. W. Guild: U.S. Geol. Survey Prof. Paper 290, 90 p., 9 pls., 35 figs., 1957; [in Portuguese] Brazil, Dept. Nac. Produção Mineral Mem. 1,217 p., 9 pls., 35 figs., 1960.

82 Reconnaissance for radioactive minerals in the southern part of Brazil, by C. T. Pierson, D. D. Haynes, and F. E. Ribeiro: U.S. Geol. Survey 
Ref. No.

Rept. TEM-1098, 28 p., 1957. Rept. prepared for U.S. Atomic Energy Comm.

83 Reservas estimadas de minérios de ferro no Quadrilátero Ferrífero, Minas Gerais, by J. V. N. Dorr 2d: Brazil, Dept. Nac. Produção Mineral Avulso 82,28 p., 1957.

84 Revisão de estratigrafia Précambriana do Quadrilátero Ferrífero, Minas Gerais, Brasil, by J. V. N. Dorr 2d, J. E. Gair, J. B. Pomerene, and G. A. Rynearson: Brazil, Dept. Nac. Produção Mineral Avulso 81, 31 p., 1957.

Uraniferous coal and carbonaceous shale in northeast Paraná, Brazil, by D. D. Haynes and C. T. Pierson: U.S. Geol. Survey Rept. TEM1097, 20 p., 1957. Rept. prepared for U.S. Atomic Energy Comm.

Uranium in the auriferous conglomerates of the Canavieiras gold mine, State of Bahia, Brazil, by M. G. White: Engenharia, Mineração e Metalurgia, v. 26, no. 155, p. 279-282, 1957; [in Portuguese] Brazil, Conselho Nac. Pesquisas, Rio de Janeiro, 11 p., 2 figs., 1957.

Age of gold mineralization at the Morro Velho and Raposos mines, Minas Gerais, by J. E. Gair: Soc. Brasileira Geologia Bol., v. 7, no. 2, p. 39-45, 1958.

88 Barreiro formation, by J. B. Pomerene: Soc. Brasileira Geologia Bol., v. 7, no. 2, p. 67-68, 1958.

89 The Batatal formation, by C. H. Maxwell: Soc. Brasileira Geologia Bol., v. 7 , no. 2 , p. $60-61,1958$.

90 The Cauê itabirite, by J. V. N. Dorr 2d: Soc. Brasileira Geologia Bol., v. 7, no. 2, p. 61-62, 1958.

91 The Cercadinho formation, by J. B. Pomerene: Soc. Brasileira Geologia Bol., v. 7, no. 2, p. 64-65, 1958.

92 Cobre na Serra da Moeda, by G. A. Rynearson: Brazil, Div. Fomento Produção Mineral Bol. 97, p. 86-89, 1958.

93 The Fecho do Funil formation, by G. C. Simmons: Soc. Brasileira Geologia Bol., v. 7, no. 2, p. 65-66, 1958.

The Gandarela formation, by J. V. N. Dorr 2d: Soc. Brasileira Geologia Bol., v. 7, no. 2, p. 63-64, 1958.

Geochemistry of trace element concentrations in the Poços de Caldas Plateau, Brazil, by G. E. Tolbert: Soc. Brasileira Geologia Bol., v. 7, no. 2, p. 71-79, 1958.

Igneous rocks, by Norman Herz, in Outline of the geology of the Quadrilátero Ferrífero, Minas Gerais, Brazil: Brazil, Dept. Nac. Produção Mineral Spec. Pub. 1 [Portuguese and English], p. 85-94, 1959; [in Portuguese] Soc. Brasileira Geologia Cong., 12th, Belo Horizonte 1958, Guia geol., p. 18-26, 1958; Engenharia, Mineração e Metalurgia, v. 28, no. 168 , p. $359-363,1958$.

97 Introduction, by J. V. N. Dorr 2d, in Outline of the geology of the Quadrilátero Ferrífero, Minas Gerais, Brazil: Brazil, Dept. Nac. Produção Mineral Spec. Pub. 1 [Portuguese and English], p. 69-70, 1959; [in Portuguese] Soc. Brasileira de Geologia Cong., 12th, Belo Horizonte 1958, Guia geol., p. 1-2, 1958; Engenharia, Mineração e Metalurgia, v. 29, no. 170, p. 75,1959 .

98 Introduction, by J. V. N. Dorr 2d, in Symposium on the stratigraphy of the Minas Series in the Quadrilátero Ferrífero, Minas Gerais, Brazil: Soc. Brasileira Geologia Bol., v. 7, no. 2, p. 57-58, 1958. rilátero Ferrífero, Minas Gerais, Brazil: Brazil, Dept. Nac. Produção 
Ref. No.

Mineral Spec. Pub. 1 [Portuguese and English], p. 99-104, 1959; [in Portuguese] Soc. Brasileira Geologia Cong., 12th, Belo Horizonte 1958, Guia geol., p. 28-33, 1958.

100 The Minas Series, by J. V. N. Dorr 2d and G. C. Simmons, in Outline of the geology of the Quadrilatero Ferrifero, Minas Gerais, Brazil: Brazil, Dept. Nac. Produção Mineral Spec. Pub. 1 [Portuguese and English], p. 72-91, 1959; [in Portuguese] Soc. Brasileira Geologia Cong., 12th, Belo Horizonte 1958, Guia geol., p. 3-11, 1958; Engenharia, Mineração e Metalurgia, v. 29 , no. 170 , p. $75-77,1959$.

101 Mineral deposits, by J. V. N. Dorr 2d, in Outline of the geology of the Quadrilátero Ferrifero, Minas Gerais, Brazil: Brazil, Dept. Nac. Produção Mineral Spec. Pub. 1 [Portuguese and English], p. 105-112, 1959; [in Portuguese] Soc. Brasileira Geologia Cong., 12th, Belo Horizonte 1958, Guia geol., p. 34-43, 1958.

102 The Moeda formation, by R. M. Wallace: Soc. Brasileira Geologia Bol., v. 7 , no. 2 , p. $59-60,1958$.

103 Phosphate minerals from the Sapucaia pegmatite mine, Minas Gerais, by W. T. Pecora and M. L. Lindberg: Soc. Brasileira Geologia Bol., v. 7, no. 2, p. 5-14, 1958.

104 Preliminary spectrochemical and age determination results on some granitic rocks of the Quadrilatero Ferrifero, Minas Gerais, Brazil, by Norman Herz and C. V. Dutra: Soc. Brasileira Cieologia Bol., v. 7, no. 2, p. 81-95, 1958.

105 Radioactive manganese occurrences in the lower Rio Itapicurú Valley, Bahia, Brazil, by D. D. Haynes, Henry Mal, and M. G. White: U.S. Geol. Survey Rept. TEM-567, 12 p., 1958. Rept. prepared for U.S. Atomic Energy Comm.

106 Reconnaissance for radioactive rocks in the Paulo Afonso region, Bahia, Brazil, by D. D. Haynes and Henry Mau: U.S. Geol. Survey Rept. TEM-1104, 8 p., 1958. Rept. prepared for U.S. Atomic Energy Comm.

107 Reconnaissance for uranium in the coal of São Paulo, Santa Catarina, and Rio Grande do Sul, Brazil, by D. D. Haynes, C. T. Pierson, and M. G. White: U.S. Geol. Survey Rept. TEM-943, 17 p., 1958. Rept. prepared for U.S. Atomic Energy Comm.

108 Rio das Velhas Series, by J. V. N. Dorr 2d, in Outline of the geology of the Quadrilátero Ferrifero, Minas Gerais, Brazil: Brazil, Dept. Nac. Produção Mineral Spec. Pub. 1 [Portuguese and English], p. 71-72, 1959; [in Portuguese] Soc. Brasileira Geologia Cong., 12th, Belo Horizonte 1958, Guia geol., p. 2-3, 1958; Engenharia, Mineração e Metalurgia, v. 29, no. 170, p. 75, 1959.

109 The Sabará formation, by J. E. Gair: Soc. Brasileira Geolngia Bol., v. 7, no. 2, p. 68-69, 1958.

110 The stratigraphy of the metamorphic rocks of the Rio de Pedras and Gandarela quadrangles, Minas Gerais, Brazil [abs.], by J. E. O'Rourke: Dissert. Abs., v. 18, no. 6, p. 2108, 1958.

111 Structure and structural evolution, by J. V. N. Dorr 2d, in Outline of the geology of the Quadrilatero Ferrífero, Minas Cerais, Brazil: Brazil, Dept. Nac. Produção Mineral Spec. Pub. 1 [Portuguese and English], p. 95-98, 1959; [in Portuguese] Soc. Brasileira Geologia Cong., 12th, Belo Horizonte 1958, Guia geol., p. 15-17, 1958.

112 Taboões quartzite, by J. B. Pomerene: Soc. Brasileira Gieologia Bol., v. 7, no. 2 , p. 66-67, 1958. 
Ref. No.

113 Uraniferous zirconium deposits of the Poços de Caldas plateau, Brazil, by G. E. Tolbert: Engenharia, Mineração e Metalurgia, v. 27, no. 161, p. 265-269; no. 162, p. 353-360, 1958.

114 Uranium in the marine phosphate deposits near Recife, State of Pernambuco, northeast Brazil, by M. G. White: Engenharia, Mineração e Metalurgia, v. 27, no. 160, p. 209-210, 1958; [in Portuguese] Brazil, Comm. Nac. Energia Nuclear, DMP/G-1, 6 p., 2 figs., 1958.

115 Excursão geológica no Nordeste, by M. G. White: Clube Mineralogia Jorn., v. 1, no. 2-3, p. 17-20, 1959.

116 Geologia de parte da Serra da Moeda, quadrícula Marinho da Serra, Minas Gerais, Brasil, by R. M. Wallace, Neuza M. P. de Mello, Brigitte Sallentien, and M. da S. Pares: Soc. Brasileira Geologia Bol., v. 8, no. 2, p. 41-56, 1959.

117 Geologic map of the Lagôa Grande quadrangle, Minas Gerais, Brazil, by R. M. Wallace: U.S. Geol. Survey open-file report, 1 map, 1959.

118 Palestra sôbre pesquisas geológicas, by J. V. N. Dorr 2d: Rev. Mineira Engenharia v. 21, no. 79, p. 25-29, 1959.

119 Pico de Itabira iron ore deposit, Minas Gerais, Brazil, by G. A. Rynearson: U.S. Geol. Survey open-file report, 1 map, 1959.

120 Preliminary geologic maps of the Belo Horizonte, Ibirite, and Macacos quadrangles, Minas Gerais, Brazil, by J. B. Pomerene: U.S. Geol. Survey open-file report, 3 maps, 1959.

121 Geologic map of the Bacão quadrangle, Minas Gerais, Brazil, by R. M. Wallace: U.S. Geol. Survey open-file report, 1 map, 1960.

122 Geologic map of the Itabirito quadrangle, Minas Gerais, Brazil, by R. M. Wallace: U.S. Geol. Survey open file report, $1 \mathrm{map}, 1960$.

123 Geologic map of the Marinho da Serra quadrangle, Minas Gerais, Brazil, by R. M. Wallace: U.S. Geol. Survey open-file report, 1 map, 1960.

124 Mapa geológico de Quadrilátero Ferrifero, Minas Gerais, Brasil, by J. V. N. Dorr 2d: Brazil, Dept. Nac. Produção Mineral, scale 1:200,000, 1960.

125 Minor element abundance in a part of the Brazilian shield, by Norman Herz and C. V. Dutra: Geochim. et Cosmochim. Acta, v. 21, p. 81-98, 1960.

126 Origin of certain cangas of the Quadrilatero Ferrifero of Minas Gerais, Brazil, by G. C. Simmons: Soc. Brasileira Geologia Bol., v. 9, no. 2, p. 37-59, 1960.

127 Resposta á presentação de Medalha José Bonifacio de Andrada e Silva, by W. D. Johnston, Jr.: Engenharia, Mineração e Metalurgia, v. 30, no. 180 , p. 326-327, 1960.

128 Age measurements from a part of the Brazilian shield, by Norman Herz, P. M. Hurley, W. H. Pinson, and H. W. Fairbairn: Geol. Soc. America Bull., v. 72, no. 7, p. 1111-1120, 1961.

129 Geologic map of the Monlevade quadrangle, Minas Gerais, Brazil, by R. G. Reeves: U.S. Geol. Survey open-file report, 1961.

130 Geologic map of the Rio Piracicaba quadrangle, Minas Gerais, Brazil, by R. G. Reeves: U.S. Geol. Survey open-file report, 1961.

131 Grupo Tamanduá da Serie Rio das Velhas, by G. C. Simmons and C. H. Maxwell: Brazil, Dept. Nac. Produção Mineral Bol. 211, 31 p., 4 figs., 1961.

132 "Laterization" of allanite in the Morro do Ferro rare earth and thorium deposit, Poços de Caldas plateau, Brazil [abs.], by Helmuth Wedow: Econ. Geology, v. 56, no. 7, p. 1335, 1961. 
Ref. No.

133 Map and sections of Andrade mine, Monlevade quadrangle, Minas Gerais, Brazil, by R. G. Reeves: U.S. Geol. Survey open-file report, 1961.

134 Metamorphic history of the Quadrilátero Ferrífero, Minas Gerais, Brazil [abs.], by Norman Herz: Geol. Soc. America Spec. Paper 68, p. 196, 1961.

135 Origin of uranium and gold in the quartzite-conglomerate of the Serra de Jacobina, Bràzil, by M. G. White: In U.S. Geol. Survey Prof. Paper 424-B, p. B8-B9, 1961.

136 Results of investigations for uranium in the Tucano basin, Bahia, Brazil, by D. D. Haynes and J. J. Matzko: In U.S. Geol. Survey Prof. Paper 424-D, p. D213-D214, 1961.

137 Revision of the geology of diamond districts in Bahia, Brazil, by M. G. White and C. T. Pierson: In U.S. Geol. Survey Prof. Paper 424-D, p. D211-D213, 1961.

138 Thorium and rare earths in the Poços de Caldas zirconium district, Brazil, by Helmuth Wedow: In U.S. Geol. Survey Prof. Paper 424-D, p. D214D216, 1961.

139 Chemical composition of Precambrian pelitic rocks, Quadrilátero Ferrifero, Minas Gerais, Brazil, by Norman Herz: In U.S. Geol. Survey Prof. Paper 450-C, p. C75-C78, 1962.

140 Geology and ore deposits of the Cachoeira do Campo, Dom Bosco, and Ouro Branco quadrangles, Minas Gerais, Brazil, by R. F. Johnson: U.S. Geol. Survey Prof. Paper 341-B, p. B1-B37, 2 pls., 13 figs., 1962.

141 Geology and ore deposits of the Nova Lima and Rio Acima quadrangles, Minas Gerais, Brazil, by J. E. Gair: U.S. Geol. Survey Prof. Paper 341-A, p. A1-A67, 8 pls., 14 figs., 1962.

142 Lead-zinc deposits of the Boquira district, State of Bahia, Brazil, by R. F. Johnson: U.S. Geol. Survey Bull. 1110-A, p. 1-33, 1962.

143 Metamorfismo do Quadrilatero Ferrifero de Minas Gerais [abs.], by Norman Herz: Acad. Brasileira Ciênc. Anais, v. 34, no. 4, p. 32, 1962.

144 Minerais de urânio e tório, by M. G. White in Guia para determinação de minerais [3d ed.], by Viktor Leinz and J. Ernesto de Souza Campos: São Paulo Univ., p. 115-133, 1962.

145 Relação entre micas cromiferas a jazidas de ouro, by G. E. Tolbert: Acad. Brasileira Ciênc. Anais, v. 34, no. 4, p. 33, 1962.

146 Canga caves of the Quadrilátero Ferrifero, Minas Gerais, Brazil, by G. C. Simmons: Natl. Speleol. Soc. Bull., v. 25, pt. 2, p. 66-72, 1963.

147 Geologia geral das quadrículas de Gravataí, Taquara, e Rolante, Rio Grande do Sul, Brasil, by R. H. Morris: Escola de Geologia, Porto Alegre, Pub. Esp. 5, p. 1-37, 5 figs., 3 maps, 1963.

148 Geology of the lead-zinc deposits in the Município de Januária, Minas Gerais, Brazil, by J. F. Robertson: U.S. Geol. Survey Bull. 1110-B, p. 35-110, pls. 3-5, figs. 4-21, 1963 [1964].

149 Geology and ore deposits of the Itabira district, Minas Gerais, by J. V. N. Dorr 2d and A. L. M. Barbosa: U.S. Geol. Survey Prof. Paper 341-C, p. C1-C110, 1963.

150 Ground-water provinces of Brazil, by Robert Schneider: U.S. Geol. Survey Water-Supply Paper 1663-A, p. A1-A14, 1 pl., 1963.

151 Origin of high grade hematite ores of Minas Gerais, Brazil [abs.], by J. V. N. Dorr 2d: Econ. Geology, v. 58, no. 7, p. 1185, 1963. 
Ref. No.

152 O papel dos servicos geológicos national no desenvolvimento dos recursos minerais, by W. D. Johnston, Jr.: Engenharia, Mineração e Metalurgia, v. 37 , no. 218 , p. $47-50,1963$.

153 Structure of gold sulfide deposits in Precambrian iron formation [abs.], by G. E. Tolbert: Econ. Geology, v. 58, no. 7, p. 1185, 1963.

154 Geochemistry of some kyanites from Brazil, by Norman Herz and C. V. Dutra: Am. Mineralogist, v. 49, no. 9-10, p. 1290-1305, 1964.

155 Geology and ore deposits of the Belo Horizonte, Ibirité, and Macacos quadrangles, Minas Gerais, Brazil, by J. B. Pomerene: U.S. Geol. Survey Prof. Paper 341-D, p. D1-D84, 1964.

156 Geology of the Raposos gold mine, Minas Gerais, Brazil, by G. E. Tolbert: Econ. Geology, v. 59, no. 5, p. 775-798, 11 figs., 1964.

157 Leucophosphite, a new occurrence in the Quadrilatero Ferrífero, Minas Gerais, Brazil, by G. C. Simmons: Am. Mineralogist, v. 49 , no. 3-4, p. 377-386, 4 figs., 1964.

158 Observações hidrólogicas no nordeste do Brasil, by D. J. Cederstrom and J. C. Assad: Brazil, Div. Geologia e Mineralogia, Notas Prelim. e Estudos 120, 42 p., 1964.

159 Reconnaissance for uranium in the central Tucano Basin, Brazil, by D. D. Haynes: U.S. Geol. Survey Bull. 1185-B, p. B1-B16, 2 pls., 1964.

160 Supergene iron ores of Minas Gerais, Brazil, by J. V. N. Dorr 2d: Econ. Geology, v. 59, no. 7, p. 1203-1240, 15 figs., 1964.

161 Uranium at Morro do Vento, Serra de Jacobina, Brazil, by M. G. White: U.S. Geol. Survey Bull. 1185-A, p. A1-A18, 2 pls., 5 figs., 1964.

162 Nature and origin of the high grade hematite ores of Minas Gerais, Brazil, by J. V. N. Dorr 2d: Econ. Geology, v. 60, no. 1, p. 1-46, 20 figs., 1965.

163 Scandium, chromium, cobalt, nickel, and niobium in biotite and the scandium geological thermometer, by Norman Herz and C. V. Dutra: Soc. Brasileira Geologia Bol., v. 13, no. 1-2. (In press.)

\section{BRITISH GUIANA}

164 Manganese deposits in the North West district, British Guiana, by B. N. Webber: British Guiana Geol. Survey Bull. 23, p. 3-45, 1952.

165 Progress report on Kurupung Placers Company, Ltd., Kurupung River, Mazuruni River district, British Guiana, by B. N. Webber: British Guiana Geol. Survey Bull. 23, p. 71-75, 1952.

166 Reconnaissance of Alex Hill and Mad Kiss mines, Cuyuni goldfields, Aurora district, Cuyuni River, British Guiana, by B. N. Webber: British Guiana Geol. Survey Bull. 23, p. 79-86, 1952.

167 Reconnaissance report on Kurupung diamond field, Mazaruni district, British Guiana, by B. N. Webber: British Guiana Geol. Survey Bull. 23, p. 45-67, 1952.

168 A brief appraisal of ground-water conditions and proposed program for water resources investigations in the coastal artesian basin of British Guiana, South America, by G. F. Worts, Jr.: British Guiana Geol. Survey Bull. 31, 52 p., 1 pl., 1958.

169 A brief appraisal of ground-water conditions in the coastal artesian basin of British Guiana, South America, by G. F. Worts, Jr.: U.S. Geol. Survey Water-Supply Paper 1663-B, p. 1-44, 1 pl., 1963. 
Ret. No.

\section{CENTRAI AMERICA}

170 Mineral deposits of Central America, by R. J. Roberts and E. M. Irving, with a section on Manganese deposits of Panama, by F. S. Simons: U.S. Geol. Survey Bull. 1034, 205 p., 16 pls., 15 figs., 1957.

\section{CHILE}

171 Geology of the Batuco lead-zinc deposits in central Chile [abs.], by J. F. MeAllister and V. E. Shainin: Econ. Geology, v. 42, no. 4, p. 417, 1947.

172 Ground-water studies in the Province of Antofagasta, Chile, by G. C. Taylor, Jr.: U.S. Geol. Survey open-file report, 25 p., 3 maps, 1947.

173 Ground-water studies in the Province of Atacama, Chile, by G. C. Taylor, Jr.: U.S. Geol. Survey open-file report, 18 p., 5 maps, 1947.

174 Ground-water studies in the Province of Coquimbo, Chile, by G. C. Taylor, Jr.: U.S. Geol. Survey open-file report, 22 p., 6 maps, 1947.

175 Ground-water studies in the Tarapacá Province, Chile, by G. C. Taylor, Jr.: U.S. Geol. Survey open-file report, 46 p., 11 maps, 1947.

176 Ground water in the valleys of Aconcagua and northern Valparaíso provinces, Chile, by G. C. Taylor, Jr.: U.S. Geol. Survey open-file report, 35 p., 5 maps, 1947.

177 Large scale shearing within an alpine glacier in the southernmost Andes [abs.], by V. E. Shainin: Geol. Soc. America Bull., v. 58, no. 12, pt. 2, p. 1226, 1947.

178 Origin of gold placers in northern Tierra del Fuego, Chile [abs.], by V. E. Shainin: Econ. Geology, v. 42, no. 4, p. 418, 1947.

179 Zoned magnetite-bearing pegmatites in central Chile [abs.], by V. E. Shainin: Econ. Geology, v. 42, no. 4, p. 417, 1947.

180 Geology and ground water of the Casablanca Basin, Chile, by G. C. Taylor, Jr.: Econ. Geology, v. 43, no. 8, p. 661-674, 4 figs., 1948.

181 Geology of tungsten deposits in north-central Chile, by J. F. McAllister and Carlos Ruiz F.: U.S. Geol. Survey Bull. 960-C, p. 89-108, pls. 21-27, figs. 8-10, 1948.

182 Ground water in the basin of the Estero Yali Province of Santiago, Chile, by G. C. Taylor, Jr.: U.S. Geol. Survey open-file report, 4 p., 1 map, 1948.

183 Ground water in the Huechun area of the Chacabuco Basin, Province of Santiago, Chile, by G. C. Taylor, Jr.: U.S. Geol. Survey open-file report, 4 p., 1 map, 1948.

184 Ground water in northern Chile, a summary, by G. C. Taylor, Jr.: Internat. Union Geodesy Geophysics, Internat. Assos. Sci. Hydrology Cong., Oslo 1948, Proc., p. 248-255, 1948.

185 Geology and ground water of the Azapa Valley, Province of Tarapaca, Chile, by G. C. Taylor, Jr.: Econ. Geology, v. 44, no. 1, p. 40-62, 5 figs., 1949.

186 Memorandum on ground-water conditions in Huachipato-Talcahuano area, near Concepción, Chile, by P. H. Jones: U.S. Geol. Survey open-file report, 8 p., 5 figs., 1 map, 1950.

187 Quicksilver deposits of Chile, by J. F. McAllister, Hector Flores W., and Carlos Ruiz F.: U.S. Geol. Survey Bull. 964-E, p. 361-400, pls. 20-30, figs. 39-44, 1950.

188 Geology and ground-water conditions in the lower valley of the Río Elqui of Chile, by P. H. Jones: U.S. Geol. Survey open-file report, 90 p., 6 pls., 40 figs., 1951. 
Ref. No.

189 Geology and ground-water conditions in the lower valley of the Río Elqui of Chile, by P. H. Jones: Econ. Geology, v. 48, no. 6, p. 457-491, 1953.

190 El agua subterránea de Santiago (Informe Preliminar), by R. J. Dingman and Lorenzo Barraza S.: Chile Inst. Inv. Geol. Bol. 1, 13 p., 1 fig., 1958.

191 Geología del cuadrángulo Cerrillos, Provincia de Atacama, by Kenneth Segerstrom and R. L. Parker: Chile Inst. Inv. Geol., Carta Geol. Chile, v. 1, no. 2, 36 p., 1 map, 1959.

192 Geología del cuadrángulo Los Loros, Provincia de Atacama, by Kenneth Segerstrom: Chile Inst. Inv. Geol., Carta Geol. Chile, v. 1, no. 1, 33 p., 1 map, 1959.

193 Definition and age of the Patagua formation, Province of Aconcagua, Chile, by W. D. Carter, Ernesto Perez, and Nelson Aliste T.: Am. Assoc. Petroleum Geologists Bull., v. 45, no. 11, p. 1892-1896, 1961; [in Spanish] Chile Inst. Ingeniería Minas, Rev. Minerales, v. 15, no. 71, p. 40-50, 1960.

194 Descripción de la geología de la región del río Copiap6, comprendida entre la Fundición Paipote y el Tranque Lautaro, by Kenneth Segerstrom: Chile Inst. Ingeniería Minas, Rev. Minerales, v. 15, no. 71, p. 24-25, 1 map, 1960.

195 Edades plomo-alfa y marco estratigráfico de granitos chilenos, con una discusión acerca de su relación con la orogénesis, by Carlos Ruiz F., Kenneth Segerstrom, Luis Aguirre, José Corvalán, H. J. Rose, Jr., and T. W. Stern: Chile Inst. Inv. Geol. Bol. 7, 26 p., 1 map, 1960.

196 Eruption of water, sand, and clay resulting from earthquake of May 21, 1960, near Concepción, Chile [abs.], by Kenneth Segerstrom: Geol. Soc. America Bull., v. 71, no. 12, pt. 2, p. 1972, 1960.

197 Geología del cuadrángulo Chamonate, Provincia de Atacama, by Kenneth Segerstrom, B. L. de Valenzuela, and Sonia Mehech: Chile Inst. Inv. Geol., Carta Geol. Chile, v. 2, no. 3, 42 p., 1 map, 1960.

198 Geología del cuadrángulo Llampos, Provincia de Atacama, by Kenneth Segeristrom: Chile Inst. Inv. Geol., Carta Geol. Chile, v. 2, no. 2, 41 p., 1 map, 1960.

199 Geología del cuadrángulo Quebrada Paipote, Provincia de Atacama, by Kenneth Segerstrom: Chile Inst. Inv. Geol., Carta Geol. Chile, v. 2, no. 1,35 p., 1 map, 1960.

200 Introducción al estudio de los microfósiles, by R. C. Douglass [rev. ed.]: Chile Univ. Escuela Geologia, 86 p., 33 pls., 1960.

201 Origin of "manto-type" copper deposits of the Cabildo mining district, central Chile, by W. D. Carter, in Genetic Problems of Ores: Internat. Geol. Cong., 21st, Copenhagen 1960, Proc., pt. 16, p. 17-28, 1960.

202 Stratigraphic setting of Chilean intrusions, their lead-alpha age, and the relation of orogeny to intrusive activity [abs.], by Carlos Ruiz F., Luis Aguirre, José Corvalán, H. J. Rose, Jr., Kenneth Segerstrom, and T. W. Stern: Geol. Soc. America Bull., v. 71, no. 12, pt. 2, p. 1963, 1960.

203 Structural geology of an area east of Copiapo, Atacama Province, Chile, by Kenneth Segerstrom: Internat. Geol. Cong., 21st, Copenhagen 1960, Proc., pt. 18, p. 14-20, 1960.

204 Age of batholithic intrusions of northern and central Chile, by Carlos Ruiz F., Luis Aguirre, José Corvalán, H. J. Rose, Jr., Kenneth Segerstrom, and T. W. Stern: Geol. Soc. America Bull., v. 72, no. 10, p. 15511560, 1 map, 1961. 
Rel. No.

205 Engineering geology and the Chilean earthquakes of 1960, by Ernest Dobrovolny and R. W. Lemke: In U.S. Geol. Survey Prof. Paper 424-C, p. C357-C359, 1961.

206 Facies change in Neocomian rocks of the Teresita-Chulo area, Atacama Province, Chile, by Kenneth Segerstrom: In U.S. Geol. Survey Prof. Paper 424-C, p. C221-C223, 1 map, 1961.

207 Rhyolite tuff, a source of the salts of northern Chile, by G. E. Ericksen:

In U.S. Geol. Survey Prof. Paper 424-C, p. C224-C225, 1961.

208 Yacimientos de cobre tipo manto; su distribución en fajas mineralizadas, Provincia de Aconcagua, Chile, by W. D. Carter: Chile Inst. Inv. Geol. Bol. 10, 30 p., 6 figs., 1961.

209 Contribución de la Corporación de Fomento al Desarrollo de Agua Subterránea en Chile, by Jaime Donoso R., and R. J. Dingman: Chile Inst. Inv. Geol. Bol. 11, 43 p., 1962.

210 Cuadrángulos Pica, Alca, Matilla, y Chacarilla, con un estudio sobre los recursos de agua subterránea, Provincia de Tarapacá, by Carlos Galli O., and R. J. Dingman: Chile Inst. Inv. Geol., Carta Geol. Chile, v. 3, nos. 2-5, 125 p., 4 maps, 1962.

211 Deflated marine terrace as a source of dune chains, Atacama Province, Chile, by Kenneth Segerstrom: In U.S. Geol. Survey Prof. Paper 450-C, p. C91-C93, 1962.

212 Geología del cuadrángulo Copiapó, Provincia de Atacama, by Kenneth Segerstrom and Carlos Ruiz F.: Chile Inst. Inv. Geol., Carta Geol. Chile, v. 3, no. 1, 115 p., 1 map, 1962.

213 Geología de la Pre-Cordillera de Copiapó, by Kenneth Segerstrom: Chile Inst. Ingeniería Minas, Rev. Minerales, v. 17, no. 76, p. 11-16, 1962.

214 Mapa metallogénico de Chile, by Carlos Ruiz F., Salomón Baranovsky, and G. E. Ericksen: Chile Inst. Inv. Geol., scale $1: 1,500,000,1962$.

215 Matureland of northern Chile and its relationship to ore deposits, by Kenneth Segerstrom: Geol. Soc. America Bull., v. 74, no. 4, p. 513-518, 2 figs., 1963; [in Spanish] Chile Inst. Ingeniería Minas, Rev. Minerales, v. 17, no. 79, p. 46-53, 2 maps, 1962.

216 Metallogenetic provinces of Chile, South America, by Carlos Ruiz F. and G. E. Ericksen: Econ. Geology, v. 57, no. 1, p. 91-106, 1962.

217 Regional geology of the Chañarcillo silver mining district and adjacent areas, Chile, by Kenneth Segerstrom: Econ. Geology, v. 57, no. 8, p. 1247-1261, 1962.

218 Structural effects related to hydration of anhydrite, Copiap6 area, Chile, by Kenneth Segerstrom: In U.S. Geol. Survey Prof. Paper 450-C, p. C28-C30, 1962.

219 Tertiary salt domes near San Pedro de Atacama, Chile, by R. J. Dingman: In U.S. Geol. Survey Prof. Paper 450-D, p. D92-D94, 1962.

220 El agua subterránea de Santiago (Segundo Informe (1958-1962), by Octavio Castillo U., Eduardo Falcón M., W. W. Doyel, and Manuel Valenzuela M.: Chile Inst. Inv. Geol. Bol. 15, 65 p., 5 illus., 16 figs., 1963.

221 Cuadrángulo Pintadas, by Kenneth Segerstrom, H. E. Thomas, and R. I. Tilling: Chile Inst. Inv. Geol., Carta Geol. Chile, no. 12, 52 p., 1 map, 1963.

222 Cuadrángulo Tulor, Provincia de Antofagasta, by R. J. Dingman: Chile Inst. Inv. Geol., Carta Geol. Chile, no. 11, 37 p., 1 map, 1963. 
Rof. No.

223 Development, organization and operation of the Instituto de Investigaciones Geológicas of Chile, by G. E. Ericksen, Carlos Ruiz F., and Bernardo Pizarro A.: United Nations Conf. Application Sci. and Tech. Benefit Less Developed Areas, Geneva 1963, v. 2, p. 45-52, 1963.

224 Eruptions of water and sand resulting from an earthquake near Concepción, Chile, by Kenneth Segerstrom, Lorenzo Casertano, and Carlos Galli O.: In U.S. Geol. Survey Prof. Paper 475-B, p. B131-B134, 1963.

225 Formation of "salt cups" near San Pedro de Atacama, Chile, by R. J. Dingman: In U.S. Geol. Survey Prof. Paper 450-E, p. E103-E104, 1963.

226 Geología de los distritos mineros Checo de Cobre, Pampa Larga y Cabeza de Vaca, Provincia de Atacama, by R. L. Parker, Raul Salas O., and Gabriel Perez R.: Chile Inst. Inv. Geol. Bol. 14, 46 p., 13 figs., 1963.

227 Geology of the salt deposits and the salt industry of northern Chile, by G. E. Ericksen: U.S. Geol. Survey open-file report, 164 p., 36 figs., 1963.

228 High marine terraces in the Caldera region of northern Chile [abs.], by Kenneth Segerstrom: Geol. Soc. America Spec. Paper 73, p. 237-238, 1963.

229 Investigaciones de geología aplicada a la ingeniería, Provincía de Concepción, by Carlos Galli O., and R. W. Lemke: Chile Inst. Inv. Geol. Bol. 13, 82 p., 10 figs., 1963.

230 Late Pleistocene diatoms from the Arica area, Chile, by R. J. Dingman and K. E. Lohman: In U.S. Geol. Survey Prof. Paper 475-C, p. C69-C72, 1963.

231 Relation between geology and the damage in Puerto Montt, Chile, caused by the earthquake of 22 May 1960, by Ernest Dobrovolny, R. W. Lemke, William Bowes, H. E. Thomas, and Nelson Bravo S.: In Oceanog., Geol., and Eng. Studies Chilean Earthquakes May 1960: Seismol. Soc. America Bull. Spec. Issue, v. 53, no. 6, p. 1299-1314, 1963.

232 Relation between the geology of Valdivia, Chile, and the damage produced by the earthquake of 22 May 1960, by W. W. Doyel, Aldo Moraga B., and Eduardo Falcón M.: In Oceanog., Geol., and Eng. Studies Chilean Earthquakes May 1960: Seismol. Soc. America Bull. Spec. Issue, v. 53, no. 6, p. 1331-1345, 1963.

233 Reversal of throw along a line of low-angle thrust faulting near San Pedro de Atacama, Chile, by R. J. Dingman: In U.S. Geol. Survey Prof. Paper 450-E, p. E25-E27, 1963.

234 Unconformity marking the Jurassic-Cretaceous boundary in the La Ligua area, Aconcagua Province, Chile, by W. D. Carter: In U.S. Geol. Survey Prof. Paper 450-E, p. E61-E63, 1963.

235 Valley widening and deepening processes in the high Andes of Chile [abs.], by Kenneth Segerstrom: Geol. Soc. America Spec. Paper 73, p. 238, 1963.

236 The artesian aquifer of the Tierra del Fuego area, Chile, by W. W. Doyel and Octavio Castillo U.: In U.S. Geol. Survey Prof. Paper 501-B, p. B169B172, 1 fig., 1964.

237 Cavities, or "tafoni," in rock faces of the Atacama Desert, Chile, by Kenneth Segerstrom and Hugo Henríquez: In U.S. Geol. Survey Prof. Paper 501-C, p. C121-C125, 5 figs., 1964.

238 Cuadrángulo Chañarcillo, by Kenneth Segerstrom and Aldo Moraga B.: Chile Inst. Inv. Geol., Carta Geol. Chile, no. 13, 50 p., 1 map, 1964.

239 Ground water in the Arica area, Chile, by W. W. Doyel: In U.S. Geol. Survey Prof. Paper 475-D, p. D213-D215, 1964. 
Rel. No.

240 Hydrogeology of the Santiago area, Chile, by W. W. Doyel, R. J. Dingman, and Octavio Castillo U.: In U.S. Geol. Survey Prof. Paper 475-D, p. D209-D212, 1964.

241 Las Melosas-El Volcán, Chile, earthquake swarm of August and September 1958 [abs.], by Pierre Saint-Amand and G. E. Ericksen: Geol. Soc. America Spec. Paper 76, p. 222-223, 1964.

242 Paleo-channels at the Guayacán copper mine, Cabildo district, Aconcagua Province, Chile, by W. D. Carter and Nelson Aliste T.: Econ. Geology, v. 59, no. 7, p. 1283-1292, 3 figs., 1964.

243 Quaternary geology of Chile: brief outline, by Kenneth Segerstrom: Geol. Soc. America Bull., v. 75, no. 3, p. 157-170, 4 figs., 1964.

244 Quaternary mudflow deposits near Santiago, Chile, by Kenneth Segerstrom, Octavio Castillo U., and Eduardo Falcón M.: In U.S. Geol. Survey Prof. Paper 475-D, p. D144-D148, 1964.

245 Geology and ground-water resources of the Pica area, Tarapaca Province, Chile, by R. J. Dingman: U.S. Geol. Survey Bull. 1189, 113 p., 1965.

\section{COLOMBIA}

246 Mineral resources of Colombia, by Q. D. Singewald: U.S. Geol. Survey Bull. 964-B, p. 53-204, pls. 5-13, figs. 2-5, 1950.

247 Fuentes de fertilizantes minerales en Colombia, by J. F. Harrington and Enrique Hubach: Colombia Servicio Geol. Nac., Ministerio Minas y Petróleos Informe 977, 10 p., 1953.

248 Segunda prospección del yacimiento de mercurio en La Esperanza, Municipio de Aranzazu, Caldas, Colombia, by J. F. Harrington and Jaime López C.: Colombia Servicio Geol. Nac., Ministerio Minas y Petroleos Informe 961, 9 p., 1953.

\section{COSTA RICA}

249 Manganese deposits in Costa Rica, by R. J. Roberts: U.S. Geol. Survey Bull. 935-H, p. 387-414, pls. 78-80, figs. 21-30, 1944.

\section{CUBA}

250 Chrome resources of Cuba, by T. P. Thayer: U.S. Geol. Survey Bull. 935-A, p. 1-74, pls. 1-20, figs. 1-6, 1942.

251 Manganese deposits of Cuba, by C. F. Park, Jr.: U.S. Geol. Survey Bull. 935-B, p. 75-97, pls. 21-24, 1942.

252 Geology and manganese deposits of Guisa-Los Negros area, Oriente Province, Cuba, by W. P. Woodring and S. N. Daviess: U.S. Geol. Survey Bull. 935-G, p. 357-386, pls. 68-77, 1944.

253 Manganese deposits in part of the Sierra Maestra, Cuba, by C. F. Park, Jr., and M. W. Cox: U.S. Geol. Survey Bull. 935-F, p. 307-355, pls. 51-67, figs. 15-18, 1944.

254 Tungsten deposits, Isla de Pinos, Cuba, by L. R. Page and J. F. McAllister: U.S. Geol. Survey Bull. 935-D, p. 177-246, pls. 32-43, 1944.

255 Petrology and structure of the Moa chromite district, Oriente Province, Cuba, by P. W. Guild: Am. Geophys. Union Trans., v. 28, no. 2, p. 218246, 1947.

256 Thrust faults and related structures in eastern Cuba, by T. P. Thayer and P. W. Guild: Am. Geophys. Union Trans., v. 28, no. 6, p. 919-930, 1947. 
Ret. No.

257 Geology and chromite deposits of the Camagüey district, Camagüey Province, Cuba, by D. E. Flint, J. F. de Albear, and P. W. Guild: U.S. Geol. Survey Bull. 954-B, p. 39-62, pls. 18-19, figs. 1-3, 1948.

258 Ground-water reconnaissance in the vicinity of Nicaro, Cuba, by N. D. Hoy: U.S. Geol. Survey open-file report, 12 p., 2 figs., 1953.

259 Geology of south-central Oriente, Cuba, by G. E. Lewis and J. A. Straczek: U.S. Geol. Survey Bull. 975-D, p. 171-366, pls. 19-22, figs. 20-44, 1955.

260 Gravity prospecting for chromite deposits in Camagüey Province, Cuba, by W. E. Davis, D. H. Richter, and W. H. Jackson: Geophysics, v. 22, no. 4, p. 848-869, 1957.

261 Geology of the manganese deposits of Cuba, by F. S. Simons and J. A. Straczek: U.S. Geol. Survey Bull. 1057, 289 p., 32 pls., 50 figs., 1958.

262 Application of gravity surveys to chromite exploration in Camagüey Province, Cuba, by W. E. Davis, W. H. Jackson, and D. H. Richter: In U.S. Geol. Survey Prof. Paper 400-B, p. B133-B136, 1960.

\section{DOMINICAN REPUBLIC}

263 Aluminous lateritic soil of the Sierra de Bahoruco area, Dominican Republic, West Indies, by S. S. Goldich and H. R. Bergquist: U.S. Geol. Survey Bull. 953-C, p. 53-84, pls. 15-19, figs. 5-7, 1947.

264 Geology and mineral resources of the Maimon-Hatillo district, Dominican Republic, by A. H. Koschmann and Mackenzie Gordon, Jr.: U.S. Geol. Survey Bull. 964-D, p. 307-359, pls. 18-19, 1950.

\section{ECUADOR}

265 El Sangay, fire-breathing giant of the Andes, by G. E. Lewis: Natl. Geog. Mag., v. 97, p. 117-138, 1950; [in Spanish] El Universo, v. 13, p. 4-5, Guayaquil, Ecuador, 1950.

\section{EGYPT}

266 Status of hydrogeological investigations in the new Valley Project, Western Desert, Egyptian Region, United Arab Republic, by H. A. Waite and H. Idris: Internat. Assoc. Sci. Hydrology Pub. 56, p. 214-225, 1961.

267 Evaluation and control of water well corrosion problems in Kharga and Dakhla Oases, Western Desert, Egypt, United Arab Republic, by F. E. Clarke: U.S. Geol. Survey open-file report, 61 p., 9 figs., 1962.

268 Appraisal of corrosion characteristics of Western Desert well waters, Egypt, by F. E. Clarke: U.S. Geol. Survey open-file report, 65 p., 19 figs., 1963.

269 Review by L. C. Conant, of "The Geology of Egypt," by Rushdi Said: Science, v. 140, p. 41, 1963.

270 Selection of metal components for long-term development of Egypt's corrosive ground waters, by F. E. Clarke: U.S. Geol. Survey open-file report, 39 p., 10 figs., 1964.

\section{BI SAIVADOR}

271 Ground-water resources of the Republic of El Salvador, Central America, by A. N. Sayre and G. C. Taylor, Jr.: U.S. Geol. Survey Water-Supply Paper 1079-D, p. 155-225, pl. 3, fig. 7, 1951. 
Ref. No.

\section{GHANA}

272 An occurrence of orbicular structure, of metasomatic origin, in the Gold Coast, by C. E. B. Conybeare: Geol. Mag., v. 88, p. 145-147, 1951.

273 On the significance of metamorphosed calcareous concretions in Lower Birrimian schists of the Gold Coast, by C. E. B. Conybeare: Geol. Mag., v. 88, p. $267-272,1951$.

\section{HAITI}

274 Manganese deposits of the Republic of Haiti, by E. N. Goddard, L. S. Gardner, and W. S. Burbank: U.S. Geol. Survey Bull. 953-B, p. 27-52, pls. 10-14, figs. 3-4, 1947.

275 Aluminous lateritic soil of the Republic of Haiti, West Indies, by S. S. Goldich and H. R. Bergquist: U.S. Geol. Survey 954-C, p. 63-109, pls. 20-22, figs. 4-7, 1948.

276 Ground-water conditions in the Plaine des Moustiques, Haiti, by G. C. Taylor, Jr.: U.S. Geol. Survey open-file report, 5 p., 1 fig., 1949.

277 Ground water in the Arcahaie plain, Haiti, by G. C. Taylor, Jr., and R. C. Lemoine: U.S. Geol. Survey open-file report, 17 p., 1 fig., 1949.

278 Ground water in the Cul-de-Sac plain, Haiti, by G. C. Taylor, Jr., and R. C. Lemoine: U.S. Geol. Survey open-file report, 60 p., 1 pl., 1949.

279 Ground water in the Gonaives plain, Haiti, by G. C. Taylor, Jr., and R. C. Lemoine: U.S. Geol. Survey open-file report, 23 p., 1 fig., 1949.

280 Ground-water reconnaissance of the Jacmel-Meyer bench, Haiti, by G. C. Taylor, Jr.: U.S. Geol. Survey open-file report, 13 p., 1 fig., 1949.

281 Ground-water reconnaissance in the Pine Forest region, Haiti, by G. C. Taylor, Jr., and R. C. Lemoine: U.S. Geol. Survey open-file report, 6 p., 1949.

282 Ground-water studies in Haiti, by G. C. Taylor, Jr.: in Prog. in Agriculture: Inst. Inter-Am. Affairs, p. 1-4, 2 figs., 1949:

283 Les rivières et les sources de la Plaine du Cul-de-Sac: les eaux souterraines dans la Plaine des Gonaives, Haiti, by G. C. Taylor, Jr., and R. C. Lemoine: Soc. Haitienne Histoire et Géographie Rev., v. 20, no. 75, p. 1-32, 1949.

284 Ground-water geology of the Gonaives plain, Haiti, by G. C. Taylor, Jr., and R. C. Lemoine: Econ. Geology, v. 45, no. 2, p. 127-141, 1950.

285 Eaux souterraines dans la Plaine de l'Arcahaie, Haiti, by G. C. Taylor, Jr., and R. C. Lemoine: Soc. Haitienne Histoire et Géographic Rev., v. 23, no. 86, p. $46-57,1952$.

\section{INDIA}

286 The occurrence of ground water in rocks of western Rajasthan, India, by G. C. Taylor, Jr.: India Natl. Inst. Sci. Bull. 1, Symposium Rajputana Desert Proc., p. 217-221, 1952.

287 Geology and ground water of the Dudhai area, eastern Kutch, India, by G. C. Taylor, Jr., and M. M. Oza: India Geol. Survey, Ser. B, Bull. 5, 75 p., 2 pls., 5 figs., 1954.

288 Geology and ground-water resources of the Anjar Khedoi region, eastern Kutch, India, by G. C. Taylor, Jr., and B. D. Pathak: India Central Board of Geophysics, Ground Water Resources Comm., Symposium Ground Water Proc., no. 4, p. 14-20, 2 maps, 1955. 
Ret. No.

289 Ground-water geology of the Pali region, Jodhpur division, western Rajasthan, India, by G. C. Taylor, Jr., A. K. Roy, D. N. Sett, and B. N. Sen: India Geol. Survey Ser. B, Bull. 6, 121 p., 1955.

290 Ground-water investigations: the basis for an operating organization, by T. E. Eakin: India Central Board of Geophysics, Ground Water Resources Comm., Symposium Ground Water Proc., no. 4, p. 372-379, 1955.

291 Manganese ore deposits of Madhya Pradesh, India, by J. A. Straczek, M. R. Subramanyam, S. Narayanaswami, K. D. Shukla, N. A. Vemban, S. C. Chakravarty, and V. Venkatesh: Internat. Geol. Cong., 20th, Mexico 1956, Symposium Yacimientos Manganeso, v. 4, p. 63-96, 1956.

292 Manganese ore deposits of the Vizagapatam district, Andhra, India, by J. A. Straczek and S. Krishnaswamy: Internat. Geol. Cong., 20th, Mexico 1956, Symposium Yacimientos Manganeso, v. 4, p. 141-149, 1956.

293 The ground-water geology of western Rajasthan, India, by G. C. Taylor, Jr., in Geohidrología Regiones Âridas y Subáradis: Internat. Geol. Cong., 20th, Mexico 1956, sec. 4, p. 257-269, 1957.

294 Geology and ground-water conditions in the Neyveli lignite area, south Arcot district, Madras State, India [abs.], by P. H. Jones and V. Subramanyam: Geol. Soc. America Bull., v. 69, no. 12, pt. 2, p. 1594, 1958; Econ. Geology, v. 53 , no. 7 , p. 920,1958 .

295 The role of production wells in the investigation and operation of groundwater reservoirs in India, by $\mathbf{A}$. A. Garrett: India Central Board Geophysics, Symposium Ground Water Proc., p. 353-364, 1958.

296 Ground-water provinces of Indit, by G. C. Taylor, Jr.: Econ. Geology, v. 54, no. 4, p. 683-697, 1959.

297 Geochemical prospecting in Khoh-Dariba copper area, Alwar district, Rajasthan, India, by J. A. Straczek, B. Srikantan, and P. G. Adyalkar: Internat. Geol. Cong., 20th, Mexico 1956, Symposium Exploración Geoquím. v. 3, p. 501-520, 1960.

298 Geochemical studies in Zawar zinc-lead area, Udaipur district, Rajasthan, India, by J. A. Straczek and K. Ganeshan: Internat. Geol. Cong., 20th, Mexico 1956, Symposium Exploración Geoquím., v. 3, p. 556-584, 1960.

299 Geology and ground-water resources of the Anjar-Khedoi region, eastern Kutch, India, with particular reference to the Kandla Port water supply, by G. C. Taylor, Jr., and B. D. Pathak: India Geol. Survey, Ser. B, Bull. 9, 339 p., 9 pls., 9 figs., 1960.

300 Ground-water control in the Neyveli lignite field, south Arcot district, Madras State, India, by P. H. Jones and V. Subramanyam: Econ. Geology, v. 56, no. 2, p. 273-297, 1961.

301 Ground water in folded Cretaceous sandstone of the Bhachau area, Kutch, India, with reference to the Kandla Port water supply, by G. C. Taylor, Jr., M. M. Oza, A. Mitra, and B. N. Sen: U.S. Geol. Survey WaterSupply Paper 1608-B, p. B1-B31, 1963.

302 Artesian water in the Malabar Coastal Plain of southern Kerala, India, by G. C. Taylor, Jr., and P. K. Ghosh: U.S. Geol. Survey Water-Supply Paper 1608-D, p. D1-D14, 1964.

\section{INDONESIA}

303 Observations on Indonesia mineral resources and their development, by E. M. Irving: Philippine Geologist, v. 10, no. 2, p. 33-51, 1956.

304 Cave deposits of phosphate rock in central Djawa, Indonesia, by R. F. Johnson and Rab. Sukamto: Djawatan Geologi Tech. Pub. 2, Econ. 
Ref. No

Geology Ser., 35 p., 1960; in U.S. Geol. Survey Prof. Paper 424-D, p. D219-D221, 1961.

305 Geology of Djartiluhur damsite and vicinity, West Java, Indonesia, by H. H. Waldron: In U.S. Geol. Survey Prof. Paper 450-D, p. D21-D23, 1962.

306 A unified classification system for soil particles, by $\mathrm{H}$. $\mathrm{H}$. Waldron: Kongres Nasional Ilmu Tanah 1, Bogor, Proc., 4 p., 1 fig., 1962.

\section{IRAN}

307 Memorandum reports on geologic spot examinations of mines and prospects in Iran, February 1954-June 1955, by Russell Gibson: U.S. Geol. Survey open-file report, 65 p., 25 figs., 1956.

\section{ISRAEL}

308 Middle Triassic marine ostracodes in Israel, by I. G. Sohn: In U.S. Geol. Survey Prof. Paper 475-C, p. C58-C59, 1963.

309 Cenomanian-Turonian aquifer of central Israel-its development and possible use as a storage reservoir, by Robert Schneider: C.S. Geol. Survey Water-Supply Paper 1608-F, p. F1-F20, 3 pls., 2 figs., 1964.

310 Relation of temperature distribution to ground-water movement in carbonate rocks of central Israel, by Robert Schneider: Geol. Soc. America Bull., v. 75, no. 3, p. 209-216, 4 figs., 1964.

\section{JAMAICA}

311 Water resources program for Jamaica, West Indies, by T. E. Eakin and C. H. Hardison: United Nations and Govt. Jamaica, 50 p., 3 figs., 1954.

312 Field meeting at Hayes Common and Round Hill, Jamaica, by G. C. Prescott and H. R. Versey: Geologists' Assoc. Proc., Jamaica section 1957, v. 69, pt. 1, p. 38-39, 1958.

313 Progress report on the geology and ground-water resources of the Clarendon Plains, Jamaica, West Indies, by H. R. Versey and G. C. Prescott: Jamaica Geol. Survey Dept. Occas. Paper 1, 27 p., 4 pls., 2 figs., 1958.

\section{JORDAN}

314 Oil possibilities in the Hashemite Kingdom of Jordan, by L. S. Gardner: Oil Forum, November, p. 448-450, 1954.

315 Geohydrologic analogies between the Jordan Valleys of Utah and the Holy Land, by Edward Bradley: Internat. Assoc. Sci. Hydrology Bull., v. 9, no. 3, p. 12-23, 8 figs., 1964.

\section{KEN YA}

316 Geology of the Wajir-Mandera district, northeast Kenya, by F. M. Ayers: U.S. Geol. Survey open-file report, 37 p., 5 figs., 4 pls., 1952.

317 Geology of the area between Wajir and Mandera, Northern Province, Kenya, by F. M. Ayers: Kenya Mines and Geology Dept. Rept. 22, 33 p., 1953.

\section{KOREA}

318 Coalfields of the Republic of Korea, part 1; Introduction by D. A. Andrews, Geology of Mungyong-Eunsong and Hwasun coalfields, by Cheong, Chang Hi: U.S. Geol. Survey Bull. 1041-A, B, p. 1-10, fig. 1, 1956. 
Ref. No.

319 Coalfields of the Republic of Korea, part 2; Geology of Macha-ri coalfield, by J. A. Reinemund, Geology of Hamback coalfield, by E. M. Baldwin, and Geology of Tangyang coalfield, by K. G. Brill, Jr.: U.S. Geol. Survey Bull. 1041-C, D, E, p. 11-99, pls. 1-11, figs. 2-13, 1957.

320 Mineral resources of Korea, by David Gallagher, M. R. Klepper, W. C. Overstreet, and R. D. Sample: U.S. Geol. Survey open-file report, 2239 p., 1 pl., 1962; U.S. Operations Mission Korea, Industry and Mining Div., 10 pts., Seoul, 1963.

321 Hydrogeological reconnaissance of South Korea, by W. W. Doyel and R. J. Dingman: In U.S. Geol. Survey Prof. Paper 501-D, p. D149-D152, 1964.

\section{LIBERIA}

322 Preliminary report on iron ore reserves at Bomi Hills, Liberia, by W. H. Newhouse, T. P. Thayer, and A. P. Butler, Jr.: U.S. Geol. Survey openfile report, 22 p., 1945.

323 Iron deposits of Liberia [abs.], by T. P. Thayer: Econ. Geology, v. 47, no. 7, p. 777-778, 1952; Geol. Soc. America Bull., v. 63, no. 12, p. 1303, 1952.

324 Phosphate mineralization at Bomi Hill and Bambuta, Liberia, West Africa, by J. M. Axelrod, T. P. Thayer, M. K. Carron, and Charles Milton: Am. Mineralogist, v. 37, no. 11-12, p. 883-909, 1952.

325 The iron deposits of western Liberia [abs.], by T. P. Thayer: Internat. Geol. Cong., 19th, Algiers 1952, Comptes rendus, sec. 10, p. 49, 1953.

\section{LIBYA}

326 A reconnaissance report on the geology and hydrology of the western part of the Province of Fezzan, United Kingdom of Libya, by H. A. Whitcomb: U.S. Geol. Survey open-file report, 128 p., 2 pls., 23 figs., 1957.

327 Reconnaissance report on the hydrology of the Gioda-Tarumin farm area, by G. C. Tibbitts, Jr.: U.S. Geol. Survey open-file report, 6 p., 1957.

328 Results of water investigations, Benghazi area, Libya, by W. W. Doyel and F. J. Maguire: U.S. Geol. Survey open-file report, 43 p., 1959.

329 A summary of the geologic history of Libya, by G. H. Gourarzi: U.S. Geol. Survey open-file report, 8 p., 1 map, 1959.

330 Water supply, Tobruk, Libya, by W. W. Doyel: U.S. Geol. Survey openfile report, 3 p., 1959.

331 Brief resumé of ground-water conditions in Libya, by J. R. Jones: U.S. Geol. Survey open-file report, 29 p., 1960.

332 Ground-water resources of the Tripoli area, Libya, by D. J. Cederstrom and Mario Bertaiola: U.S. Geol. Survey open-file report, $20 S$ p., 21 figs., 1960.

333 Significance of decline in ground-water levels in Tripolitania, Libya, as determined by pumping-tests, by W. T. Stuart: U.S. Geol. Survey openfile report, 29 p., 1960.

334 Tables of well records in the Tripoli area to accompany text: Ground-water resources of the Tripoli area, by D. J. Cederstrom and Mario Bertaiola: U.S. Geol. Survey open-file report, 153 p., 1960.

335 Ground water in the Azzahra-Annisira-Al Amiria area, Tripolitania, by Mario Bertaiola: U.S. Geol. Survey open-file report, 36 p., 1961.

336 Man-made changes in the water resources of Tripolitania, Libya, by C. Vita-Finzi and R. C. Vorhis: Internat. Assoc. Sci. Hydrology, Athens 1961, Symposium ground water in arid zones, Pub. 57, p. 530-531, 1961. 
Ref. No.

337 Exploration of the Jefren gypsum-anhydrite deposits, Libya, by J. L. Gualtieri: U.S. Geol. Survey open-file report, 65 p., 11 pls., 3 figs., 1962.

338 Ground-water resources of Al Mayah area, Tripolitania, United Kingdorn of Libya, by William Ogilbee, R. C. Vorhis, and Fituri Deghaies: U.S. Geol. Survey open-file report, 83 p., 9 figs., 1962.

339 Ground-water resources of the Qarahbulli area, Tripolitania, United Kingdom of Libya, by William Ogilbee and Hadi Ali Tarhuni: U.S. Geol. Survey open-file report, 93 p., 10 figs., 1962.

340 Idri salt deposits, Fezzan Province, Libya, by G. H. Goudarzi: U.S. Geol. Survey open-file report, 36 p., 5 pls., 7 figs., 1962.

341 Iron deposits of the Shatti Valley area of Fezzan Province, Libya, by G. H. Goudarzi: U.S. Geol. Survey open-file report, 77 p., 38 pls., 10 figs., 1962.

342 Marada, Pisida, Idri and Tauorga salt deposits of Libya, by G. H. Goudarzi: U.S. Geol. Survey open-file report, 28 p., 13 pls., 1962.

343 Pisida saline deposits, Libya, by G. H. Goudarzi: U.S. Geol. Survey openfile report, 29 p., 3 pls., 1962.

344 Report on the ground-water potential of an area near Gasr bu Hadi, Libya, as determined by pumping tests, by William Ogilbee: U.S. Geol. Survey open-file report, 19 p., 1962.

345 Topographic map of the Kingdom of Libya, by G. H. Goudarzi: U.S. Geol. Survey Misc. Geol. Inv. Map I-350 B, scale 1:2,000,000, 1962.

346 Ground-water exploration in Al Marj area, Cyrenaica, by T. G. Newport and Yousef Haddar: U.S. Geol. Survey Water Supply Paper 1757-A, p. A1-A24, 1963.

347 Ground-water resources of the Az Zawiyak area, Tripolitania, United Kingdom of Libya, by William Ogilbee and R. C. Vorhis: U.S. Geol. Survey open-file report, 77 p., 9 figs., 1963.

348 Ground-water resources of the Surman area, Tripolitania, United Kingdom of Libya, by William Ogilbee, R. C. Vorhis, and Aurelio Russo: U.S. Geol. Survey open-file report, 75 p., 9 figs., 1963.

349 Progress report on proposed land reclamation and resettlement project near Bir el Ghnem, Tripolitania, Libya, by J. R. Jones and F. M. Tileston: U.S. Geol. Survey open-file report, 9 p., 1963.

350 Water for municipal use at Agedabia, Libya, by J. R. Jones: U.S. Geol. Survey open-file report, 21 p., 1 fig., 1963.

351 Geologic map of Libya, by L. C. Conant and G. H. Goudarzi: C.S. Geol. Survey Misc. Geol. Inv. Map I-350 A, scale 1:2,000,000, 1964.

352 Ground water in the Sirte area, Tripolitania, United Kingdom of Libya, by William Ogilbee: U.S. Geol. Survey Water-Supply Paper 1757-C, p. C1-C14, 1964.

353 Ground-water maps of Libya, by J. R. Jones: U.S. Geol. Survey open-file report, 24 p., 6 figs., 1964.

354 Ground-water resources of the Bengási area, Cyrenaica, United Kingdom of Libya, by W. W. Doyel and F. J. Maguire: U.S. Geol. Surver WaterSupply Paper 1757-B, p. B1-B21, 1964.

\section{MEXICO}

355 Tin deposits of the Republic of Mexico, by W. F. Foshag and Carl Fries, Jr.: U.S. Geol. Survey Bull. 935-C, p. 99-176, pls. 25-31, figs. 10, 11, 1942; [in Spanish] Mexico Consejo Recursos Naturales no Renovables Bol. 8, 66 p., 6 pls., 3 figs., 1946. 
Ref. No.

356 The Mexican volcano Parícutin, by P. D. Trask: Science, v. 98, no. 2554, p. 501-505, 1943.

357 Early history of the Mexican volcano, Parícutin, by P. D. Trask: Am. Geophys. Union Trans., 25th Ann. Mtg., pt. 4, p. 617-618, 1945.

358 Parícutin's cyclic activity, by D. E. White: Am. Geophys. Union Trans., 25th Ann. Mtg., pt. 4i, p. 621-628, 2 figs., 1945.

359 Quicksilver-antimony deposits of Huitzuco, Guerrero, Mexico, by J. F. McAllister and David Hernández O.: U.S. Geol. Survey Bull. 946-B, p. 49-71, pls. 7-24, figs. 7-13, 1945; [in Spanish] Mexico Consejo Recursos Naturales no Renovables Bol. 6, 31 p., 18 pls., 7 figs., 1946.

360 Scheelite deposits in the northern part of the Sierra de Juárez, Northern

Territory, Lower California, Mexico, by Carl Fries, Jr., and Eduardo Schmitter: U.S. Geol. Survey Bull. 946-C, p. 73-101, pls. 25-38, fig. 14, 1945; [in Spanish] Mexico Consejo Recursos Naturales no Renovables Bol. 2, 42 p., 14 illus., 1 fig., 1945.

361 Tungsten deposits of the southern part of Sonora, Mexico, by J. H. Wiese and Salvador Cárdenas: U.S. Geol. Survey Bull. 946-D, p. 103-130, pls. 39-44, figs. 15-17, 1945; [in Spanish] Mexico Consejo Recursos Naturales no Renovables Bol. 3, 48 p., 6 illus., 3 figs., 1946.

362 Activity of Parícutin during its third year, by K. B. Krauskopf and Howel Williams: Am. Geophys. Union Trans., v. 27, no. 3, p. 406-411, 1946.

363 Coal deposits of the Santa Clara district near Tónichi, Sonora, Mexico, by I. F. Wilson and V. S. Rocha: U.S. Geol. Survey Bull. 962-A, p. 1-80, pls. 1-12, figs. 1-3, 1949; [in Spanish] Mexico Consejo Recursos Naturales no Renovables Bol. 9, 108 p., 9 illus., 8 figs., 1946.

364 Los depósitos de fluorita del distrito minero de Taxco, Estado de Guerrero, México, by W. F. Foshag, Jenaro González-Reyna, and Rafael Pérez S.: Mexico, Minas y Petróleo Bol., v. 17, no. 7, p. 3-8; no. 8, p. 3-7, 1946.

365 Geology of the Cuarento mercury district, State of Durango, Mexico, by David Gallagher and Rafael Pérez S.: U.S. Geol. Survey Bull. 946-F, p. 155-168, 1 pl., 2 figs., 1946; [in Spanish] Mexico Consejo Recursos Naturales no Renovables Bol. 13, 21 p., 1 pl., 2 figs., 1947.

366 Informe preliminar de la zona minera de "El Cuarenta," Municipio de San Bernardo, Estado de Durango, by Rafael Pérez S. and David Gallagher: Mexico, Minas y Petróleo Bol., v. 17, no. 4, p. 3-7, 1946.

367 Informe sobre la geología de los craideros de mercurio en la zona minera de Nuevo Mercurio, Distrito de Mazapíl, Estado de Zacatecas, México, by Rafael Pérez S. and David Gallagher: Mexico, Minas y Petróleo Bol. v. 17 , no. 5 , p. $3-6,1946$.

368 San José antimony mines near Wadley, State of San Luis Potosí, México, by D. E. White and Jenaro González-Reyna: U.S. Geol. Survey Bull. 946-E, p. 131-153, pls. 45-50, figs. 18-22, 1946; [in Spanish] Mexico Consejo Recursos Naturales no Renovables Bol. 14, 36 p., 6 illus., 5 figs., 1947.

369 Activity of Parícutin volcano from May 4 to September 18, 1946, by Kenneth Segerstrom and Celedonio Gutiérrez: Am. Geophys. Union Trans., v. 28, no. 4, p. 559-566, 3 maps, 1 fig., 1947.

370 Activity of Parícutin volcano from September 18 to November 30, 1946, by R. E. Wilcox: Am. Geophys. Union Trans., v. 28, no. 4, p. 567-572, 1947.

371 Activity of Parícutin volcano from December 1, 1946, to March 31, 1947, by R. E. Wilcox: Am. Geophys. Union Trans., v. 28 , no. 5, p. 725-731, 1947. 
Ref. No.

372 Antimony deposits of the Tejocotes region, State of Oaxaca, Mexico, by D. E. White and Reinaldo Guiza, Jr.: U.S. Geol. Survey Bull. 953-A, p. 1-26, pls. 1-9, figs. 1-2, 1947; [in Spanish] Mexico Consejo Recursos Naturales no Renovables Bol. 15, 37 p., 9 illus., 2 figs., 1947.

373 Carta geológica de la parte septentrional de la República Mexicana, by P. B. King: Mexico Univ. Nac. Autonoma, Inst. Geología, Geofísica y Geodesía, Cartas Geológicas y Mineras, no. 3, 24 p., 1947.

374 Diagenetic origin of chert lenses in limestone at Soyatal, State of Querétaro, Mexico, by D. E. White: Am. Jour. Sci., v. 245, p. 49-55, 5 figs., 1947. Surveying Mexico's minerals, by Carl Fries, Jr.: Modern Mexico, v. 20, no. 1, p. 14-15, 22, 1947.

376 Activity of Parícutin volcano from April 1 to July 31, 1947, by R. E. Wilcox: Am. Geophys. Union Trans., v. 29, no. 1, p. 69-74, 1948.

377 Activity of Parícutin volcano from August 1 to November 30, 1947, by R. E. Wilcox and Samuel Shoup O.: Am. Geophys. Union Trans., v. 29, no. 1, p. 74-79, 1948.

378 Activity of Parícutin volcano from December 1, 1947, to March 31, 1948, by R. E. Wilcox: Am. Geophys. Union Trans., v. 29, no. 3, p. 355-360, 1948.

379 Activity of Parícutin volcano from April 1 to July 31, 1948, by R. E. Wilcox and Celedonio Gutiérrez: Am. Geophys. Union Trans., v. 29, no. 6, p. 877-881, 1948.

380 Antimony deposits of the Soyatal district, State of Querétaro, Mexico, by D. E. White: U.S. Geol. Survey Bull. 960-B, p. 35-86, pls. 9-20, figs. 4-7, 1948; [in Spanish] Mexico Consejo Recursos Naturales no Renovables Bol. 21, 78 p., 12 illus., 7 figs., 1949.

381 Buried topography, initial structures, and sedimentation in Santa Rosalía area, Baja California, Mexico, by I. F. Wilson: Am. Assoc. Petroleum Geologists Bull., v. 32, p. 1762-1807, 1948; [in Spanish] Mexico Univ. Nac. Autonoma, Inst. Geologia, Geofísica y Geodesía, Bol. 53, 78 p., 1948.

382 Geology of the Huahuaxtla mercury district, State of Guerrero, Mexico, by David Gallagher and Rafael Pérez S.: U.S. Geol. Survey Bull. 960-E, p. 149-175, 3 pls., 3 figs., 1948; [in Spanish] Mexico Consejo Recursos Naturales no Renovables Bol. 27, 30 p., 3 pls., 3 figs., 1950.

383 Lava movement at Parícutin volcano, Mexico, by K. B. Krauskopf: Geol. Soc. America Bull., v. 59, no. 12, pt. 1, p. 1267-1284, 7 figs., 2 pls., 1948.

384 Optical calcite deposits of the Republic of Mexico, by Carl Fries, Jr.: U.S. Geol. Survey Bull. 954-D, p. 113-179, pls. 23-32, 1948; [in Spanish] Mexico Consejo Recursos Naturales no Renovables Bol. 16, 93 p., 10 illus., 8 figs., 1948.

385 Manganese deposits of Mexico, by P. D. Trask and José Rodríquez C.: U.S. Geol. Survey Bull. 954-F, p. 209-315, pl. 39, 1948; [in Spanish] Mexico Consejo Recursos Naturales no Renovables Bol. 19, 158 p., 1948. 386 Manganese deposits of the Talamantes district near Parral, Chihuahua, Mexico, by I. F. Wilson and V. S. Rocha: U.S. Geol. Survey Bull. 954-E, p. 181-208, pls. 33-38, fig. 16, 1948; [in Spanish] Mexico Consejo Recursos Naturales no Renovables Bol. 18, 39 p., 2 illus., 8 figs., 1948.

387 Mechanism and eruption at Parícutin volcano, Mexico, by K. B. Krauskopf: Geol. Soc. America Bull., v. 59, no 8, p. 711-732, 13 figs., 2 pls., 1948.

388 Some aspects of cooperation with Mexico in geological investigations, by Carl Fries, Jr.: U.S. Dept. State, Record, v. 4, p. 1-6, 1948. 
Ref. No.

389 Tin-bearing placers near Guadalcázar, State of San Luis Potosí, Mexíco, by Carl Fries, Jr., and Eduardo Schmitter: U.S. Geol. Survey Bull. 960-D, p. 109-149, pls. 28-33, fig. 11, 1948; [in Spanish] Mexico Consejo Recursos Naturales no Renovables Bol. 17, 50 p., 6 pls., 1 fig., 1948.

390 Antimony deposits of El Antimonio district, Sonora, Mexico, by D. E. White and Reinaldo Guiza, Jr.: U.S. Geol. Survey Bull. 962-B, p. 81-119, pls. 13-25, figs. 4-5, 1949; [in Spanish] Mexico Consejo Recursos Naturales no Renovables Bol. 23, 48 p., 13 illus., 2 figs., 1949.

391 Brevas notas acerca de la clasificación y nomenclatura de los sedimentos y rocas sedimentarias, by Carl Fries, Jr.: Soc. Geol. Mexicana Bol., v. 14, p. 101-111, 1949.

392 Geology and manganese deposits of the Lucifer district, northwest of Santa Rosalía, Baja California, Mexico, by I. F. Wilson and Mario Veytia: U.S. Geol. Survey Bull. 960-F, p. 177-233, pls. 37-54, fig. 15, 1949 ; [in Spanish] Mexico Consejo Recursos Naturales no Renovables Bol. 25, 68 p., 18 illus., 1 fig., 1949.

393 Geomorphic events of east-central Mexico [abs.], by C. H. Behre, Jr., and Carl Fries, Jr.: Geol. Soc. America Bull., v. 60, no. 12, pt. 2. p. 1873, 1949.

394 The phlogopite industry of Oaxaca, Mexico, by D. M. Larrabee and Amadeo Larralde: Cong. Panam. Engenharia Minas e Geología, 2d, Petropolis 1946, Anais, v. 2, p. 353-368, 1949.

395 Activity of Parícutin volcano from August 1, 1948, to June 30, 1949, by Carl Fries, Jr., and Celedonio Gutiérrez: Am. Geophys. Union Trans., v. 31 , no. 3 , p. $406-418,1950$.

396 Activity of Parícutin volcano from July 1 to December 31, 1949, by Carl Fries, Jr., and Celedonio Gutiérrez: Am. Geophys. Union Trans., v. 31, no. 5, p. 732-740, 1950.

397 Erosion studies at Parícutin, State of Michoacán, Mexico, by Kenneth Segerstrom: U.S. Geol. Survey Bull. 965-A, 164 p., 7 maps, 73 figs., 1950.

398 Tin deposits of the State of Durango, Mexico, by W. C. Smith, Kenneth Segerstrom, and Reinaldo Guiza, Jr.: U.S. Geol. Survey Bull. 962-D, p. 155-204, pls. 32-49, 1950; [in Spanish] Mexico Consejo Recursos Naturales no Renovables Bol. 36, 72 p., 18 illus., 1957.

399 Volcanoes of the Parícutin region, Mexico, by Howel Williams: U.S. Geol. Survey Bull. 965-B, p. 165-279, pls. 8-9, figs. 74-94, 1950.

400 Activity of Parícutin volcano from January 1 to June 30, 1950, by Carl

Fries, Jr., and Celedonio Gutiérrez: Am. Geophys. Union Trans., v. 32 no. 2, p. 212-221, 1951.

401 Activity of Parícutin volcano from July 1 to December 31, 1950, by Carl Fries, Jr., and Celedonio Gutiérrez: Am. Geophys. Union Trans., v. 32, no. 4 , p. 572-581, 1951.

402 Activity of Parícutin volcano from January 1 to June 30, 1951, by Carl Fries, Jr., and Celedonio Gutiérrez: Am. Geophys. Union Trans., v. 33, no. 1, p. 91-100, 1952.

403 Activity of Parícutin volcano from July 1 to December 31, 1951, by Carl Fries, Jr., and Celedonio Gutiérrez: Am. Geophys. Union Trans., v. 33, no. 5, p. 725-733, 1952.

404 Esstudio mineralógico de los minerales auro-argentíferos del Distrito de Guanajuato, México [abs.], by Charles Milton, Alfredo Terrazas, I. F. Wilson, and J. R. Houston: Convención Interam. Recursos Minerales, 1st, Mexico 1951, Mem., p. 72-73, 1952. 
Ref. No.

405 Geology of the quicksilver deposits of Canoas, Zacatecas, Mexico, by David Gallagher: U.S. Geol. Survey Bull. 975-B, p. 47-84, 5 pls., 2 figs., 1952; [in Spanish] Mexico Consejo Recursos Naturales no Renovables Bol. 39, 54 p., 5 pls., 2 figs., 1957.

406 Los depósitos de fosfatos de Concepción del Oro Zacatecas, by C. L. Rogers, Salvador Ulloa A., and Eugenio Tavera A.: Convención Interam. Recursos Minerales, 1st, Mexico 1951, Mem., p. 83-91, 1952.

407 Phosphate deposits of the Concepción del Oro district, Zacatecas, Mexico, by C. L. Rogers, Salvador Ulloa A., and Eugenio Tavera A.: U.S. Geol. Survey open-file report, 11 p., 1952.

408 Relación entre los cuerpos de mineral costeable y los diques en el Distrito de Pachuca-Real del Monte, Estado de Hidalgo, México [abs.], by A. R. Geyne and I. F. Wilson: Convención Interam. Recursos Minerales, 1st, Mexico 1951, Mem., p. 270, 1952.

409 Hidalgoite, a new mineral, by R. L. Smith, F. S. Simons, and A. C. Vlisidis: Am. Mineralogist, v. 38, no. 11-12, p. 1218-1224, 1953.

410 Los depósitos fosforíticos de la región de Concepción del Oro y Mazapíl, Zacatecas, México, by C. L. Rogers, Salvador Ulloa A., and Eugenio Tavera A.: Internat. Geol. Cong., 19th, Algiers 1952, Comptes rendus sec. 11 , pt. 11, p. 33-43, 1953.

411 Sección estratigráfica en un pozo profundo de agua en Rosita, Coahuila, México, by R. C. Robeck: Asoc. Mexicana Geólogos Petroleros, v. 5, no. 9-10, p. 363-365, 1953.

412 Volumes and weights of pyroclastic material, lava, and water erupted by Parícutin volcano, Michoacán, Mexico, by Carl Fries, Jr.: Am. Geophys. Union Trans., v. 34, no. 4, p. 603-616, 1953.

413 Activity of Parícutin volcano during 1952, by Carl Fries, Jr., and Celedonio Gutiérrez: Am. Geophys. Union Trans., v. 35, no. 3, p. 486-494, 1954.

414 Petrology of Parícutin volcano, Mexico, by R. E. Wilcox: U.S. Geol. Survey Bull. 965-C, p. 281-354, pls. 10-11, figs. 95-107, 1954.

415 Discovery of early Cenozoic vertebrates in the red conglomerate at Guanajuato, Mexico, and its significance to Mexico geology, by Carl Fries, Jr., C. W. Hibbard, and D. H. Dunkle: Smithsonian Inst. Misc. Colln., v. 123 , no. 7 , p. $1-25,1955$.

416 Geology and mineral deposits of the Boleo copper district, Baja California, Mexico, by I. F. Wilson in collaboration with V. S. Rocha: U.S. Geol. Survey Prof. Paper 273, 134 p., 11 pls., 38 figs., 1955; [in Spanish] Mexico Consejo Recursos Naturales no Renovables Bol. 41, 424 p., 11 illus., 46 figs., 1957.

417 Studies of some early Tertiary red conglomerates of central Mexico, by J. D. Edwards: U.S. Geol. Survey Prof. Paper 264-H, p. 153-185, pls. 45-47, figs. 17-40, 1955; [in Spanish] Internat. Geol. Cong., 20th, Mexico 1956, Mon., 75 p., 6 illus., 15 figs., 1956.

418 Un banco calizo del Cretácico de la parte oriental del Edo. de Querétaro, México, by B. W. Wilson, J. P. Hernández, and Eduardo Meave T.: Soc. Geol. Mexicana Bol., v. 18, no. 1, p. 1-10, 1955.

419 The birth and development of Parícutin volcano, by W. F. Foshag and Jenaro González-Reyna: U.S. Geol. Survey Bull. 965-D, p. 355-489, pls. 12-51, figs. 108-123, 1956.

420 Bosquejo geológico de las partes central y occidental del Estado de Morelos $\mathrm{y}$ áreas contiguas de los Estados de Guerrero y México, by Carl Fries, 
Ref. No.

Jr.: Internat. Geol. Cong., 20th, Mexico 1956, Libreto-guía Excursión C-9, p. 17-53, 64-134, 1956.

421 Bosquejo geológico de la región entre México, D. F. y Acapulco, Guerrero, by Carl Fries, Jr.: Internat. Geol. Cong., 20th, Mexico 1956, Libretoguía Excursiones A-9 and C-12, p. 7-53, 1956; Asoc. Mexicana Geólogos Petroleros Bol., v. 9, no. 5-6, p. 287-333, 2 maps, 1956 (1957).

422 Bosquejo geológico de la región entre México, D. F., y Taxco, Guerrero, by Carl Fries, Jr.: Internat. Geol. Cong., 20th, Mexico 1956, Libretoguía Excursiones A-4 and C-2, p. 11-36, 39-64, figs. 1-6, 1956.

423 Estratigrafía y tectónica del Cenozóico entre México, D. F., y Zimapán, Hidalgo, y Guía de campo, ruta México D. F., Zimapán, Hidalgo, by Kenneth Segerstrom: Internat. Geol. Cong., 20th, Mexico 1956, Libretoguía Excursiones $\mathrm{A}-3$ and $\mathrm{C}-1$, p. 11-37, 2 maps, and Libreto-guía Excursiones A-14 and C-6, p. 153-178 and 311-323, 2 maps, 1956.

424 The Gavilán manganese deposits, Baja California, by I. F. Wilson: Internat. Geol. Cong., 20th, Mexico 1956, Symposium sobre Yacimientos Manganeso, v. 3, p. 119-124, 1956.

425 General geology and phosphate deposits of Concepción del Oro district, Zacatecas, Mexico, by C. L. Rogers, Zoltán de Cserna, Eugenio Tavera A., and Salvador Ulloa A.: U.S. Geol. Survey Bull. 1037-A, 102 p., pls. 1-2, figs. 1-27, 1956; [in Spanish] Mexico Consejo Recursos Naturales no Renovables Bol. 38, 152 p., 2 pls., 27 figs., 1957.

426 Geología del distrito cuprífero del Boleo, Baja California, by I. F. Wilson: Internat. Geol. Cong., 20th, Mexico 1956, Excursiones A-1 and C-4, p. 53-68, 1956.

427 Geología y depósitos de carbón de la región de Sabinas, Estado de Coahuila, by R. C. Robeck, Ruben Pesquera V., and Salvador Ulloa A.: Internat. Geol. Cong., 20th, Mexico 1956, 103 p., 13 illus., 2 figs., 1956.

428 Geología de la mina de manganeso "Lucifer" en Baja California, México, by I. F. Wilson: Internat. Geol. Cong., 20th, Mexico 1956, Excursiones A-1 and C-4, p. 69-78, 1956.

429 Geología general y rocas volcánicas del área entre México, D. F. y Huauchinango, y guía de campo, ruta México, D. F., Huauchinango, Puebla, by Kenneth Segerstrom: Internat. Geol. Cong., 20th, Mexico 1956, Libreto-guía Excursiones A-10 and C-13, p. 13-40, 2 maps, 1956.

430 Geología y yacimientos minerales del distrito minero de Zimapán, Estado de Hidalgo, by F. S. Simons and Eduardo Mapes V.: Internat. Geol. Cong., 20th, Mexico 1956, Libreto-guía Excursiones $\mathrm{A}-3$ and $\mathrm{C}-1$, figs. 5-7, 1956.

431 Geology and ore deposits of the Zimapán mining district, Hidalgo, Mexico, by F. S. Simons and Eduardo Mapes V.: U.S. Geol. Survey Prof. Paper 284, 128 p., 14 pls., 69 figs., 1956; [in Spanish] Mexico Consejo Recursos Naturales no Renovables Bol. 40, 288 p., 16 pls., 65 figs., 1957.

432 Itincrario Tamazunchale-Zimapán and Itinerario Zimapán-Tamazunchale, by A. J. Bodenlos: Internat. Geol. Cong., 20th, Mexico 1956, Libreto-guía Excursiones A-14 and C-6, p. 119-152, 179-215, 1956.

433 The Lucifer manganese deposits, Baja California, Mexico, by I. F. Wilson: Internat. Geol. Cong., 20th, Mexico 1956, Symposium sobre Yacimientos Manganeso, v. 3, p. 97-108, 1956.

434 Manganese deposits of La Abundancia and La Esperanza mines, Zacatecas, Mexico, by I. F. Wilson and V. S. Rocha: Internat. Geol. Cong., 20th, 
Ref. No.

Mexico 1956, Symposium sobre Yacimientos Manganeso, v. 3, p. 141-149, 1956.

435 Manganese deposits of the $M_{i} \cdot n$ taña de Manganeso mine, San Luis Potosí, Mexico, by I. F. Wilson ana V. S. Rocha: Internat. Geol. Cong., 20th, Mexico 1956, Symposium sobre Yacimientos Manganeso, v. 3, p. 133-139, 1956.

436 Manganese deposits of the Sierra de Borregos, Chihuahua, Mexico, by I. F. Wilson: Internat. Geol. Cong., 20th, Mexico 1956, Symposium sobre Yacimientos Manganeso, v. 3, p. 109-117, 1956.

437 Notas sobre la geología de la Sierra Madre en la sección Zimapán-Tamazunchale, by A. J. Bodenlos: Internat. Geol. Cong., 20th, Mexico 1956, Libreto-guía Excursiones A-14 and C-6, p. 293-310, 1956.

438 The Talamantes manganese deposits, Chihuahua, by I. F. Wilson and V. S. Rocha: Internat. Geol. Cong., 20th, Mexico 1956, Symposium sobre Yacimientos Manganeso, v. 3, p. 125-132, 1956.

439 Investigación sobre lateritas fósiles en las regiones sureste de Oaxaca y sur de Chiapas, by B. N. Webber and Jesús Ojeda R.: Mexico Consejo Recursos Naturales no Renovables Bol. 37, 72 p., 10 illus., 23 figs., 1957.

440 Elaboración del mapa base, by B. H. Kent, pt. 1 of Elaboración de mapas a partir de fotografías aéreas: Soc. Geol. Mexicana Bol., v. 22, no. 1, 1959.

441 Métodos para transferir detalles fotográficos a les mapas base, by B. H. Kent, pt. 2 of Elaboración de mapas a partir de fotografías aéreas: Soc. Geol. Mexicana Bol., v. 22, no. 1, 1959.

442 Como tomer medidas de las fotos aéreas, by B. H. Kent, pt. 3 of Elaboración de mapas a partir de fotografías aćreas: Soc. Geol. Mexicana Bol., v. 22, no. 2, 1959.

443 Erosion and related phenomena at Parícutin in 1957, by Kenneth Segerstrom: U.S. Geol. Survey Bull. 1104-A, 18 p., 10 figs., 1960.

444 Geology of the state of Morelos and contiguous areas in south-central Mexico, by Carl Fries, Jr.: U.S. Geol. Survey open-file report, 210 p., 22 pls., 2 figs., 1959; [in Spanish] Mexico Inst. Geología Bol. 60, 236 p., 1960.

445 Deceleration of erosion at Parícutin, Mexico, by Kenneth Segerstrom: In U.S. Geol. Survey Prof. Paper 424-D, p. D225-D227, 1 map, 2 figs., 1961.

446 Estratigrafía del area Bernal-Jalpán, Estado de Querétaro, by Kenneth Segerstrom: Asoc. Mexicana Geólogos Petroleros Bol., v. 13, no. 5-6, p. $183-206,1961$.

447 Geology of the Bernal-Jalpán area, State of Querétaro, Mexico, by Kenneth Segerstrom: U.S. Geol. Survey Bull. 1104-B, p. 19-86, 1 map, 24 figs., 1961.

448 Geology of south-central Hidalgo and northeastern Mexico State, Mexico, by Kenneth Segerstrom: U.S. Geol. Survey Bull. 1104-C, p. 87-162, 1 map, 1962; [in Spanish] Asoc. Mexicana Geólogos Petroleros Bol., v. 13 , p. $147-168,1$ map, 1961.

449 Investigation of the principal fluorspar districts of Mexico, by R. E. Van Alstine: In U.S. Geol. Survey Prof. Paper 424-C, p. C212-C215, 1 fig., 1961.

450 Mapa geológico de reconocimiento y secciones estructurales de la región de San Blas y El Fuerte, estados de Sinaloa y Sonora, by Zoltán de Cserna and B. H. Kent: Mexico Inst. Geología, Cartas Geol. y Mineras, no. 4, 1961. 
Ref.No.

451 Marine phosphorites of north-central Mexico, by C. L. Rogers, Eugenio Tavera A., Jesús Ojeda R., Zoltán de Cserna, and Roger van Vloten: In U.S. Geol. Survey Prof. Paper 424-D, p. D222-D224, 1961.

452 Pachuca mining district, Hidalgo, Mexico, by A. R. Geyne, Carl Fries, Jr., Kenneth Segerstrom, R. F. Black, and I. F. Wilson: In U.S. Geol. Survey Prof. Paper 424-D, p. D221-D222, 1961.

453 Reconocimiento geológico y depósitos de fosfatos del norte de Zacatecas y areas adyacentes en Coahuila, Nuevo León y San Luis Potosí, by C. L. Rogers, Zoltán de Cserna, Eugenio Tavera A., Roger van Vloten, and Jesús Ojeda R.: Mexico Consejo Recursos Naturales no Renovables Bol. 56, 322 p., 31 pls., 3 maps, 1961.

454 Investigations of the principal fluorspar districts of Mexico, by R. E. Van Alstine: U.S. Geol. Survey open-file report, 98 p., 1963; [in Spanish] Mexico Consejo Recursos Naturales no Renovables Bol. 62, 62 p., 9 illus., 1 map, 1962.

455 Tectonic framework of an area within the Sierra Madre Oriental and adjacent Mesa Central, north-central Mexico, by C. L. Rogers, Zoltán de Cserna, Jesús Ojeda R., Eugenio Tavera A., and Roger van Vloten: U.S. Geol. Survey Prof. Paper 450-C, p. C21-C24, 1962.

456 Geology and mineral deposits of the Pachuca-Real del Monte district, State of Hidalgo, Mexico, by A. R. Geyne, Carl Fries, Jr, Kenneth Segerstrom, R. F. Black, I. F. Wilson, and Alan Probert: Mexico Consejo Recursos Naturales no Renovables Pub. 5E [Spanish and English], 222 p., 20 pls., 115 figs., 1963.

457 Plutonic rocks of northern Zacatecas and adjacent areas, Mexico, by C. L. Rogers, Roger van Vloten, Jesús Ojeda R., Eugenio Tavera A., and Zoltán de Cserna: In U.S. Geol. Survey Prof. Paper 475-C, p. C7-C10, 1963.

458 The use of air photographs in the development of the natural resources of Mexico, by José Perez L., Felipe Guerra P., S. H. Sanchez M., B. H. Kent, and Antonio García R.: United Nations Conf. Application Sci. and Tech. Benefit Less Developed Areas, Geneva 1963, v. 2, p. 183-193, 1963.

\section{NICARAGUA}

459 Conditions of ground water on the plateau of La Sierras, Nicaragua, by G. C. Taylor, Jr.: U.S. Geol. Survey open-file report, 3 p., 1943.

460 Memorandum concerning proposed water supply development at Lake Tiscapa, Managua, Nicaragua, by A. N. Sayre: U.S. Geol. Survey openfile report, 9 p., 1943.

461 Ground-water data, Nicaragua, by S. L. Schoff: U.S. Geol. Survey openfile report, 25 p., 4 illus., 2 maps, 1956.

462 Ground water for irrigation at La Calera, Nicaragua, by S. L. Schoff: U.S. Geol. Survey open-file report, 7 p., 1956.

\section{NIGERIA}

463 Geochemical prospecting investigations in the Nyeba lead-zinc district, Nigeria, by H. E. Hawkes: U.S. Geol. Survey Bull. 1000-B, p. 51-103, figs. $1-13,1954$.

\section{N YASALAND}

464 The geology of the Blantre-Limbe area, by B. E. Ashley, D. N. Holt, and and S. W. Morel: Nyasaland Geol. Survey, Ann. Rept. 1950, p. 3-5, 1950.

465 Notes on some reconnaissance traverses in the Neno district, by B. E. Ashley: Nyasaland Geol. Survey, Ann. Rept. 1950, p. 5-6, 1950. 
Ref. No.

466 The geology of the Neno district, by B. E. Ashley, with Note on the Mlindi Ring structure by W. G. G. Cooper: Nyasaland Geol. Survey, Ann Rept. 1951, p. 4-5, 1951.

\section{PAKISTAN}

467 Geology of the development tunnel area, Makarwal collieries, Mianwali district, West Pakistan, by Walter Danilchik: Paskistan Geol. Survey Adm. Rept. 4, 8 p., illus., 1958.

468 An investigation of alluvial sands for uranium and minerals of economic importance; the Indus, Gilgit, Nagar, and Hunza Rivers, Gilgit Agency, West Pakistan, by Walter Danilchik and R. A. K. Tahirkheli: Pakistan Geol. Survey Inf. Release 11, 12 p., 1959.

469 Bentonite deposits near Padhrar, Rawalpindi division, West Pakistan, by R. G. Bogue and R. G. Schmidt: Pakistan Geol. Survey Mineral Inf. Circ. 3, 24 p., 1961.

470 Celestite deposits near Thano Bula Khan, Hyderabad division, West Pakistan, by R. G. Bogue: Pakistan Geol. Survey Mineral Inf. Cire. 2 18 p., 1961.

471 The iron formation of the Surghar and western Salt Ranges, Mianwali district, West Pakistan, by Walter Danilchik: In U.S. Geol. Survey Prof. Paper 424-D, p. D228-D231, 1961.

472 Quarterly report of the Radioactive Minerals Unit, Geological Survey of Pakistan, for July, August, and September 1961, by R. G. Schmidt and S. A. Asad: Pakistan Geol. Survey Adm. Circ. 1, 9 p., 1961.

473 Barite deposits of Pakistan, by F. L. Klinger and S. H. Abbas: Central Treaty Organization, Symposium Indus. Rocks and Minerals, Lahore 1962, Proc., p. 418-428, 1 fig., 1962.

474 Beach placers containing radioactive minerals, Bay of Bengal, East Pakistan, by R. G. Schmidt and S. A. Asad: In U.S. Geol. Survey Prof. Paper 450-C, p. C12-C14, 1962.

475 Cost estimate for concentrating low-grade chromite ore, Hindubagh district, Baluchistan, West Pakistan, by R. G. Bogue: Pakistan Geol. Survey Mineral Inf. Circ. 1, 20 p., 1962.

476 Examination of fuller's earth deposits, Thano Bula Khan, Dadu district, Hyderabad division, West Pakistan, by R. G. Bogue: Pakistan Geol. Survey Mineral Inf. Circ. 4, 14 p., 1962.

477 Introductory mineralogic studies of chromite, Hindubagh and Ft. Sandeman districts, Baluchistan, West Pakistan, by R. G. Bogue: Pakistan Geol. Survey Interim Geol. Rept. 1, 1962.

478 Magnesite in Pakistan, by Roger van Vloten: Central Treaty Organization, Symposium Indus. Rocks and Minerals, Lahore 1962, Proc., p. 211-215, 1 fig., 1962.

479 New records of fossil elasmobranch fishes from West Pakistan, by D. H. Dunkle and A. N. Fatmi: Pakistan Geol. Survey Paleont. and Strat. Note 1, 9 p., 1962.

480. Quarterly report of the Radioactive Minerals Unit, Geological Survey of Pakistan, for October, November, and December 1961 by R. G. Schmidt and S. A. Asad: Pakistan Geol. Survey Adm. Circ. 2, 21 p., 1962.

481 Uranium mineralization near Rakhimunh village, Dera Ghazi Khan district, West Pakistan, by S. A. Asad and R. G. Schmidt: Pakistan Geol. Survey Mineral Inf. Circ. 5, 15 p., 1962. 
Ref. No.

482 The application of photogeology and photogrammetry to geological surveys of natural resources in Pakistan, by W. R. Hemphill and A. H. Kidwai: United Nations Conf. Application Sci. and Tech. Benefit Less Developed Areas, Geneva 1963, v. 2, p. 194-206, 1963.

483 A cooperative mineral exploration and development program in Pakistan, by N. M. Kahn and J. A. Reinemund: United Nations Conf. Application Sci. and Tech. Benefit Less Developed Areas, Geneva 1963, v. 2, p.71-89, 5 figs., 1963.

484 Geology of the iron deposits of Pakistan, by F. L. Klinger, J. A. Reinemund, and M. G. White: Central Treaty Organization, Symposium Iron Ore, Esphahan 1963, p. 101-111, 1963.

485 The ground-water hydrology of the Punjab, West Pakistan, by D. W. Greenman, G. D. Bennett, and W. V. Swarzenski: Pakistan Water and Power Devel. Authority Bull. 6, 98 p., 1963.

486 Hydrology and scientific reclamation in the Punjab, West Pakistan, by D. W. Greenman: United Nations Conf. Application Sci. and Tech. Benefit Less Developed Areas, Geneva 1963, v. 1, p. 332-342, 1963.

487 Manganese deposits at Sanjro near Bela Kalat division, West Pakistan, by R. G. Bogue: Pakistan Geol. Survey Mineral Inf. Circ. 9, 14 p., 1 fig., 1963.

488 A minimum program for mineral resources evaluation, by M. G. White, J. J. Matzko, and Asrarullah: United Nations Conf. Application Sci. and Tech. Benefit Less Developed Areas, Geneva 1963, v. 2, p. 118-131, 1963.

489 Preliminary geological map of proposed coal mine development near Sharigh, West Pakistan, by R. L. Harbour and M. Y. Khan: Pakistan Geol. Survey Adm. Circ. 3, 1963.

490 A reconnaissance survey of radioactive beach sand at Cox's Bazar, East Pakistan, by R. G. Schmidt and S. A. Asad: Pakistan Geol. Survey Interim Geol. Rept. 3, 13 p., 6 figs., 1963.

491 Stratigraphic research as applied to mineral resources exploration and development in Pakistan, by D. H. Dunkle, Curt Teichert, and Habib-ur Rahman: United Nations Conf. Application Sci. and Tech. Benefit Less Developed Areas, Geneva 1963, v. 2, p. 173-182, 1963.

492 Geology and ground-water investigations in the Punjab Plain, West Pakistan, by Z. U. Kidwai and W. V. Swarzenski: West Pakistan Eng. Cong., Lahore 1963, Proc., 15 p. (In press.)

493 Mineral deposits of the southern part of the Hazara district, West Pakistan, by J. A. Calkins, T. W. Offield, and S. T. Ali.: Pakistan Geol. Survey Interim Geol. Rept., illus. incl. geol. sketch map $1: 250,000$. (In press.)

\section{PANAMA}

494 Geology and paleontology of Canal Zone and adjoining parts of Panama, by W. P. Woodring: U.S. Geol. Survey Prof. Paper 306-A, p. 1-145, pls. 1-23, figs. 1-4, 1957.

495 Ground water in Herrera Province and adjoining areas in Coclé, Los Santos, and Veraguas provinces, Panama, by G. C. Taylor, Jr.: U.S. Geol. Survey open-file report, 20 p., 1 pl., 2 figs., 1949.

496 Tertiary formations of Panama Canal Zone adjoining parts of Panama, by W. P. Woodring and T. F. Thompson: Am. Assoc. Petroleum Geologists Bull., v. 33, no. 2, p. 223-247, 1949. 
Ref. No.

\section{PARAGUAY}

497 Posibilidad de establecer industrias minerales en el Paraguay, by E. B. Eckel and Ricardo Mazo: Centro Estudiantes Ciênc. Econ. Rev., v. 13, no. 110 , p. 45-51, 1952.

498 Igneous petrology of Paraguay [abs.], by Charles Milton and E. B. Eckel: Geol. Soc. America Bull., v. 65, no. 12, pt. 2, p. 1286, 1954.

499 Geologic map of Paraguay, in Geology and mineral resources of Paraguaya reconnaissance, by E. B. Eckel: U.S. Geol. Survey Prof. Paper 327, pl. 1, scale $1: 1,000,000,1959$.

500 Geology and mineral resources of Paraguay-a reconnaissance, by $\mathbf{E}$. B. Eckel, with sections by Charles Milton and P. T. Sulsona: U.S. Geol. Survey Prof. Paper 327, 110 p., 3 pls., 58 figs., 1959.

\section{PERU}

501 Geology of the Huancavelica quicksilver district, Peru, by R. G. Yates, D. F. Kent, and Jaime Fernández C.: U.S. Geol. Survey Bull. 975-A, p. 1-45, 6 pls., 5 figs., 1951.

502 El problema de los aluviones de la Cordillera Blanca, by P. D. Trask: Soc. Geog. Lima Bol., v. 70, Tercero y Cuarto Trimestre, 75 p., 1953.

503 Some desert features of northwest central Peru, by F. S. Simons and G. E. Ericksen: Soc. Geol. Perú Bol., v. 26, p. 229-246, 1 fig., 1953.

504 The Cusco, Peru earthquake of May 21, 1950, by G. E. Ericksen, Jaime Fernández C., and Enrique Silgado: Seismol. Soc. America Bull., v. 44, no. 2 A, p. 97-112, 1954.

505 Los depósitos minerales de la Provincia de Cajatambo, Perú, by R. W. Lewis, Jr., and Sigfredo Narváez L.: Peru Inst. Nac. Inv. y Fomento Mineros Bol. 13, p. 21-43, 1955.

506 Geology of the Atacocha mine, Department of Pasco, Peru, by R. F. Johnson Econ. Geology, v. 50, no. 3, p. 249-270, 1955.

507 Geology and ore deposits of the Atacocha district, Department of Pasco, Peru, by R. F. Johnson, R. W. Lewis, Jr., and Guillermo Abele C.: U.S. Geol. Survey Bull. 975-E, p. 337-388, pls. 23-30, figs. 45-52, 1955.

508 Lead-zinc deposits of Cordillera Blanca and northern Cordillera Huayhuash, Peru, by A. J. Bodenlos and G. E. Ericksen: U.S. Geol. Survey Bull. 1017, 166 p., 12 pls., 33 figs., 1955.

509 The lead-zinc veins of the Chilete mining district in northern Peru, by F. $\mathbf{S}$. Simons: Econ. Geology, v. 50, no. 4, p. 399-419, 11 figs., 1955.

510 Los yacimientos de plomo y zinc de la region de Río Pallanga, by R. F. Johnson and Alberto Manrique P.: Peru Inst. Nac. Inv. y Fomento Mineros Bol. 13, p. 3-20, 1955.

511 Geología del distrito minero de Hualgayoc, Departamento de Cajamarca, by G. E. Ericksen, Mariano Iberico M., and Ulrich Petersen B.: Peru Inst. Nac. Inv. y Fomento Mineros Bol. 16, 99 p., 1956.

512 The geology and mineralogy of the Castrovirreyna mining district, by $R$. W. Lewis, Jr.: Soc. Geol. Perú Bol., v. 30, p. 217-224, 1956.

513 The geology and ore deposits of the Quiruvilca district, Peru, by $R$. W. Lewis, Jr.: Econ. Geology, v. 51, no. 1, p. 41-63, 1956; [in Spanish] Inst. Ingenieros Minas Perú Minera 14, 1956.

514 Hypogene veins of northern Peru, by G. E. Ericksen: Soc. Geol. Perú Bol., v. 30, p. 141-157, 1956.

515 The iron deposit of Cerro Huacravilca, Junín; Peru, by F. S. Simons and Eleodoro Bellido B.: Soc. Geol. Perú Bol., v. 30, p. 359-374, 1 map, 1956. 
Ref. No.

516 Mapa geológico del Perú, by Eleodoro Bellido B., Sigfredo Narváez L., and F. S. Simons: Soc. Geol. Perú, 2 sheets, scale 1:2,000,000, 1956.

517 A note on Pur-Pur dune, Virú Valley, Peru, by F. S. Simons: Jour. Geology, v. 64, no. 5, p. 517-521, 2 figs., 1956.

518 Las vetas do plomo y zinc en la región minera de Chilete, en el norte del Perú, by F. S. Simons: Soc. Nac. Minería y Petróleo, Lima, Bol. 50, p. 3-24, 1956.

519 Base metal deposits of the Cordillera Negra, Departamento de Ancash, Peru, by A. J. Bodenlos and J. A. Straczek: U.S. Geol. Survey Bull. 1040, 165 p., 14 pls., 18 figs., 1957.

520 Memoria explicativa del mapa geologico del Perú, by Eleodoro Bellido B., and F. S. Simons: Soc. Geol. Perú Bol., v. 31, 88 p., 1957.

521 Depósitos de plomo y zinc de la Cordillera Negra, Departamento de Ancash, Perú, by A. J. Bodenlos and J. A. Straczek: Minería, Lima, v. 6, no. 21-23, p. 140-151, 182-195, 232-247, 1957; v. 7, no. 24, p. 3-15, 1958; also Soc. Nac. Minería y Petróleo, Lima, Bol. 55-58, p. 89-98, 130-141, 170-183, 225-235, 1957; Bol. 59, p. 3-15, 1958.

522 Ground-water resources of the Lambayeque Valley, Peru, by S. L. Schoff and J. L. Sayán M: U.S. Geol. Survey open-file report, 281 p., 19 figs., 6 pls., 1959.

523 Plan regional para el desarrollo del sur de Perú, Informes, v. 2, no. 5, Los recursos minerales, by Thor Kiilsgaard and Eleodoro Bellido B.: Lima, Serv. Cooperativo Interam. Plan Sur, p. 1-146, figs. 1-16, 1959.

524 Plan regional para el desarrollo del sur de Perú, Informes, v. 2, no. 6, Los recursos de carbón y petróleo, by W. W. Olive: Lima, Serv. Cooperativo Interam. Plan Sur, 24 p., 1959.

525 Plan regional para el desarrollo del sur de Perú, Informes, v. 3, Reconocimiento de las aguas subterraneas, by S. L. Schoff and J. L. Sayán M.: Lima, Serv. Cooperativo Interam. Plan Sur, 157 p., 1959.

526 A reconnaissance of ground water in southern Peru-a review of present and possible future development, by S. L. Schoff and J. L. Sayán M.: U.S. Geol. Survey open-file report, 258 p., 30 figs., 12 pls., 1960.

527 Geología del distrito minero de Sayapullo, Departamento de Cajamarca, Peru, by G. E. Ericksen, Dante Brambilla, and Guillermo Abele C.: Soc. Geol. Perú Bol., v. 37, p. 5-26, 10 figs., 1962.

528 Geology, mineralogy, and paragenesis of the Castrovirreyna lead-zinc-silver deposits, Peru, by R. W. Lewis, Jr.: U.S. Geol. Survey open-file report, 265 p., 56 figs., 15 pls., 1964.

\section{PHIIIPPINES}

529 The role of the geologist in industrialization, by E. M. Irving: Philippine Geologist, v. 1, no. 1, p. 20-24, 1946.

530 Geomorphological implications of the Marikina drainage pattern, Rizl Province, Luzon, Philippines, by E. M. Irving: Philippine Geologist, v. 1, no. 2, p. 1-12, 1947.

531 Guano caves of Pupug, Municipality of Mabini, Bohol, Philippines, by E. M. Irving and J. S. Teves: Philippine Geologist, v. 1, no. 4, p. 1-8, 1947.

532 Laguna de Bay as a potential natural resource, by E. M. Irving: Philippine Geologist, v. 1, no. 3, p. 12-20, 1947.

533 Application of engineering geology in reduction and maintenance costs of the Dewey Boulevard sea wall, by E. M. Irving and N. S. Fernandez: Philippine Geologist, v. 2, no. 4, p. 24-25, 1948. 
Ref. No.

534 The Iloilo earthquake of January 25, 1948, Panay Island, by E. M. Irving and J. S. Teves: Philippine Geologist, v. 2, no. 2, p. 6-17, 1948.

535 Reconnaissance geology of the Burgos-Pasuquin area, Ilocos Norte-a demonstration in modern reconnaissance methods, by E. M. Irving and J. C. Quema: Philippine Geologist, v. 2, no. 3, p. 1-17, 1948.

536 Commentary on the proposed flood control and drainage system for Manila, by E. M. Irving and L. F. Abad: Philippine Geologist, v. 3, no. 3, p. 4-11, 1949.

537 The significance of figures, by E. M. Irving: Philippine Geologist, v. 3, no. 4, p. I, 1949.

538 Notes on the geology of Balabac Island, Palawan, Philippines, by E. M. Irving: Philippine Geologist, v. 3, no. 4, p. 14-22, 1949.

539 Philippine coal, foreign exchange and power development, by E. M. Irving: Philippine Geologist, v. 3, no. 3, p. 1-3, 1949.

540 Pointers for Philippine prospectors, by E. M. Irving: Philippine Geologist, v. 4, no. 1, p. 14-17, 1949.

541 Iron in southern Samar, by E. M. Irving: Philippine Geologist, v. 4, no. 4, p. 1-6, 1950.

542 Notes on the geology of the basement complex along the Bokod Trail, Mountain Province, Luzon, by E. M. Irving and Generoso Oca: Philippine Geologist, v. 4, no. 3, p. 11-23, 1950.

543 Notes on the geology of the Gold Star iron mines, Mogpog, Marinduque, Philippines, by E. M. Irving: Philippine Geologist, v. 5, no. 1, p. 26-38, 1950.

544 Notes on the geology of the Lusteveco silver-lead mine, Looc, Panagsagan, Batangas, Philippines, by E. M. Irving: Philippine Geologist, v. 4, no. 2, p. 17-22, 1950.

545 Notes on the geology of the Rapu-Rapu Island, Albay Province, by E. M. Irving and D. P. Cruz: Philippine Geologist, v. 5, no. 1, p. 1-11, 1950.

546 Possible source of phosphate fertilizer for the Philippines, by J. C. Quema and E. M. Irving: Philippine Bur. Mines Inf. Circ. 9, p. 1-33, 1950.

547 A potential nickle-platinum mine at the Acoje chromite mine, Santa Cruz, Zambales, by E. M. Irving and C. D. Hulin: Philippine Geologist, v. 4, no. 4, p. 11-16, 1950.

548 Review of Philippine basement geology and its problems, by E. M. Irving: Philippine Jour. Sci., v. 79, no. 3, p. 267-307, 1950.

549 Summary of the geology of the Malangas Sibuguey coalfield, Zambeanga Province, Mindanao, by G. F. Brown: Philippine Jour. Sci., v. 79, no. 2, p. 155-163, 1950.

550 Discovery of the largest single known source of sulfur in the Philippines, by E. M. Irving: Philippine Geologist, v. 6, no. 1, p. 1-4, 1951.

551 Geologic reports on the copper-pyrite deposits of Rapu-Rapu Island, Albay Province, Philippines, by E. M. Irving and D. P. Cruz: Philippine Bur. Mines Rept. Inv. 1, 24 p., 1951.

552 Notes on the occurrence of manganese ores on the Anda Peninsula, Bohol Island, Philippines, by E. M. Irving: Philippine Geologist, v. 6, no. 1, p. 19-24, 1951.

553 Review of geochemistry and its possible application in the Philippines, by E. M. Irving: Philippine Geologist, v. 5, no. 2, p. 47-78, 1951.

554 Submarine morphology of the Philippine Archipelago and its geological significance, by E. M. Irving: Philippine Jour. Sci., v. 80, no. 1, p. 55-88, 1951. 
Ref. No.

555 Geological history and petroleum possibilities of the Philippines, by E. M. Irving: Am. Assoc. Petroleum Geologists Bull., v. 36, no. 3, p. 437-476, 1952.

556 An integrated power, flood control, water supply and irrigation development scheme for the metropolitan Manila area, by E. M. Irving: Philippine Geologist, v. 7, no. 1, p. I, 1952.

557 Industrial possibilities in Philippine mineral resources fields, by E. M. Irving: Philippine Mining Yearbook, p. 9-13, 1952.

558 Physiographic observations on Mindanao by aerial reconnaissance, and their geological interpretation, by E. M. Irving: Philippine Jour. Sci., v. 81 , no. 2 , p. 141-169, 1952.

559 Sebu Lakes, southeast Cotabato Province, as a site for hydroelectric power development, by E. M. Irving: Philippine Geologist, v. 6, no. 3, p. 66-71, 2 pls., 1952.

560 Coal resources of eastern Batan Island, Albay Province; progress report [abs.], by J. M. Weller and O. A. Crispin: Pacific Sci. Cong., 8th, Philippines 1953, Abs. Papers, p. 27-28, 1953.

561 A geologic map (biostratigraphic-lithologic) of the Philippines, by $\mathbf{E}$. M. Irving: Philippine Bur. Mines, 10 sheets, scale 1:1,125,000, 1953.

562 Geology of the Bulalacao region, southeastern Mindoro, preliminary report [abs.], by J. M. Weller and J. F. Vergara: Pacific Sci. Cong., 8th, Philippines 1953, Abs. Papers, p. 25-26, 1953.

563 The phosphate deposits of Angaur Island, Palau group, western Carolines [abs.], by E. M. Irving: Pacific Sci. Cong., 7th, New Zealand 1949, Proc., v. 2, p. 248-249, 1953.

564 Problems in the basement complex geology of Philippines [abs.], by E. M. Irving: Pacific Sci. Cong., 7th, New Zealand 1949, Proc., v. 2, p. 22, 1953.

565 Note on the first discovery of commercial mercury in the Philippines, by E. M. Irving: Philippine Geologist, v. 9, no. 1, p. 1-7; Mining Newsletter, v. 6, no. 2, p. 84-88, 109, Manila, 1954.

566 Note on the recent chromite discovery near Puerto Princesa, Palawan Island, by E. M. Irving: Mining Newsletter, v. 6, no. 1, p. 9-12, Manila, 1954; Philippine Geologist, v. 8, no. 4, p. 94-98, 1954.

567 Corrections and addenda to: Note on the recent chromite discovery near Puerto Princesa, Palawan, by E. M. Irving: Philippine Geologist, v. 9, no. 2, p. 42-43, 1955.

568 Geology and coal resources of Batan Island, Albay, by O. A. Crispin, J. M. Weller, and J. F. Vergara: Philippine Bur. Mines Spec. Proj. Ser., no. 3, 51 p., 1955.

569 Geology and coal resources of the Bulalacao region, Mindoro Oriental, by J. M. Weller and J. F. Vergara: Philippine Bur. Mines Spec. Proj. Ser., no. 1,37 p., 1955.

570 Geology and coal resources of the Gatbo Peninsula, Bacon-Prieto DiazGubat region, Sorsogon, Philippines, by C. B. Ibañez, Harley Barnes, and Juan de la Cruz: Philippine Bur. Mines Spec. Proj. Ser., no. 5, 16 p., 2 pls., geologic map, scale 1:25,000, 1955.

571 Geology and coal resources of the Hitoma-Manambrag region, Catanduanes, by Victor de los Santos and J. M. Weller: Philippine Bur. Mines Spec. Proj. Ser., no. 4, 26 p., 1955.

572 Geology and coal resources of the Panganiban region, Catanduanes, by J. M. Weller, O. A. Crispin, and C. B. Ibañez. Philippine Bur. Mines Spec. Proj. Ser., no. 2, 23 p.; 1955. 
Ref. No.

573 Preliminary report on the geology of the copper deposits east of Sipalay, Negros Occidental, by A. R. Kinkel, Jr., Luis Santos-Yñigo, F. U. Francisco, and Sisenando Samaniego: Philippine Bur. Mines Rept. Inv. 13, 24 p., 1955.

574 Copper deposits of the Philippines, by A. R. Kinkel, Jr., Luis Santos-Yñigo, Sisenando Samaniego, and O. A. Crispin: Philippine Bur. Mines Spec. Proj. Ser., no. 16; pt. 1 (text), 305 p., and pt. 2 (plates), 1956; [abs.]: Washington Acad. Sci., Jour., v. 48, no. 4, p. 138, 1958.

575 Geology of the Botolan copper mine, Botolan, Zambales, by A. R. Kinkel, Jr., and Sisenando Samaniego: Philippine Bur. Mines Spec. Proj. Ser., no. 10,12 p., 1956.

576 Geology and coal resources of the Argao-Dalaguete region, Cebu, Philippines, by Harley Barnes, C. P. Jongco, G. C. Lazaga, J. E. Pilac, and H. E. Vokes: Philippine Bur. Mines Spec. Proj. Ser., no. 7, 52 p., 8 pls., geologic maps, scales $1: 25,000$ and 1:5,000, 1956.

577 Geology and coal resources of the Malangas-Kabasalan region, Zamboanga del Sur, Philippines, by C. B. Ibañez, I. S. Antonio, Harley Barnes, and Luis Santos-Yñigo: Philippine Bur. Mines Spec. Proj. Ser., no. 8, 73 p., 10 pls., geologic maps, scales 1:25,000 and 1:5,000, 1956.

578 Geology of the copper deposits of the Hixbar Gold Mines, Inc., Rapu-Rapu Island, Albay, by A. R. Kinkel, Jr., and Sisenando Samaniego: Philippine Bur. Mines Spec. Proj. Ser., no. 9, 23 p., 1956.

579 Geology of three major manganese districts of the Philippines, by $\mathbf{R}$. K. Sorem: Pacific Sci. Cong., 8th, Philippines 1953, Proc., v. 2-A, p. 661$668,1956$.

580 Manganese deposits of the Anda Peninsula, Bohol Island, Philippines, by R. K. Sorem, N. S. Fernandez, and D. N. Palacio: Philippine Bur. Mines Spec. Proj. Ser., no. 11, 48 p., 1956.

581 A new geologic map of the Philippines [abs.], by E. M. Irving: Pacific Sci. Cong., 8th, Philippines 1953, Proc., v. 2, p. 259, 1956.

582 Problems in the origin of phosphate ores of Angaur Island, Palau group, western Carolines [abs.], by E. M. Irving: Pacific Sci. Cong., 8th, Philippines 1953, Proc., v. 2-A, p. 593, 1956; Mining Newsletter, v. 7, no. 5, p. 161-162, Manila, 1956.

583 Problems of tectogenesis in the Philippine archipelago [abs.], by E. M. Irving: Pacific Sci. Cong., 8th, Philippines 1953, Proc., v. 2-A, p. 867, 1956.

584 Chromite in the Zambales Range [abs.], by J. W. Peoples, N. S. Fernandez, Sisenando Samaniego, and Miguel de la Cruz: Geol. Soc. America Bull., v. 68 , no. 12 , pt. 2 , p. $1778,1957$.

585 Coal resources of the Philippines, by F. D. Spencer and J. F. Vergara: Philippine Bur. Mines Spec. Proj. Ser., no. 20, 52 p., 1957.

586 Geology and coal resources of Bislig-Lingig region, Surigao, Philippines, by F. D. Spencer and J. F. Vergara: Philippine Bur. Mines Spec. Proj. Ser., no. 14, 62 p., 1957.

587 Geology and coal resources of the Calatrava-Toboso region, Occidental Negros, Republic of Philippines, by M. M. Melendres, Jr., and Harley Barnes: Philippine Bur. Mines Spec. Proj. Ser., no. 12, 50 p., 5 pls., geologic maps, scales 1:25,000 and 1:5,000, 1957.

588 Progress report on exploration on Insular Chromite Reservation Parcel No. 1, Masinloc, Zambales, Philippines, by J. W. Peoples, N. S. Fer- 
Ref. No.

nandez, and C. A. Fontanos: Philippine Bur. Mines Rept. Inv. 16, 6 p., 1957.

589 Ultramafic and mafic rocks of the Zambales Range, Luzon, Philippines [abs.], by M. L. Gonzales, J. W. Peoples, N. S. Fernandez, and Visitacion Victorio: Geol. Soc. America Bull., v. 68, no. 12, pt. 2, p. 1736, 1957.

590 Geology of a Philippine coal field [abs.], by Harley Barnes: Washington Acad. Sci. Jour., v. 48, no. 4, p. 138-139, 1958.

591 Origin of manganese deposits of Busuanga Island, Philippines, by R. K. Sorem: U.S. Geol. Survey open-file report, 134 p., 1 pl., 26 figs., 1958.

592 Chromite deposits on Insular Chromite Reservation No. 1, Zambales, Philippines, by D. L. Rossman, N. S. Fernandez, C. A. Fontanos, and Z. C. Zepeda: Philippine Bur. Mines Spec. Proj. Ser., no. 19, 12 p., 3 pls., 1959.

593 Reconnaissance sampling of the black sands of northern and western Luzon, by J. B. Pomerene, O. A. Crispin, J. E. Pilac, and J. F. Harrington: Philippine Bur. Mines Rept. Inv. 25, 23 p., 1960.

594 Explanatory notes to a regional geological map of the Philippine Islands, by E. M. Irving, in Econ. Comm. Asia and Far East Geol. Map of Asia and Far East: 6 sheets, scale 1:5,000,000, 1961.

595 Hydrogeologic reconnaissance of Poro Point, La Union Province, Luzon, Philippines, by G. F. Worts, Jr.: U.S. Geol. Survey Water-Supply Paper 1608-E, p. E1-E14, 1964.

\section{SAODI ARABIA}

596 Ground water in the Nejd, Saudi Arabia [abs.], by R. A. Bramkamp and G. F. Brown: New York Acad. Sci. Trans., Sec. 2, v. 10, p. 236-237, 1948.

597 The geology and ground water of Al Kharj district, Nejd, Saudi Arabia, by G. F. Brown: New York Acad. Sci. Trans., sec. 2, v. 10, p. 370-375, 1949.

598 Geographic map of the southern Tuwayq quảdrangle, Kingdom of Saudi Arabia, by R. A. Bramkamp, R. D. Gierhart, G. F. Brown, and R. O. Jackson: U.S. Geol. Survey Misc. Geol. Inv. Map I-212 B, scale $1: 500,000$, 1956.

599 Geologic map of the southern Tuwayq quadrangle, Kingdom of Saudi Arabia, by R. A. Bramkamp, R. D. Gierhart, G. F. Brown, and R. O. Jackson: U.S. Geol. Survey Misc. Geol. Inv. Map I-212 A, scale 1:500,000, 1956.

600 Geographic map of the northern Tuwayq quadrangle, Kingdom of Saudi Arabia, by R. A. Bramkamp and L. F. Ramirez: U.S. Geol. Survey Misc. Geol. Inv. Map I-207 B, scale 1:500,000, 1957.

601 Geographic map of the Arabian Peninsula, Kingdom of Saudi Arabia, by G. F. Brown and others: U.S. Geol. Survey Misc. Geol. Inv. Map I-270 B-1, scale $1: 2,000,000,1958$.

602 Geographic map of the Asir quadrangle, Kingdom of Saudi Arabia, by G. F. Brown and R. O. Jackson: U.S. Geol. Survey Misc. Geol. Inv. Map I-217 B, scale 1:500,000, 1958.

603 Geographic map of the southern Hijaz quadrangle, Kingdom of Saudi Arabia, by G. F. Brown and R. O. Jackson: U.S. Geol. Survey Misc. Geol. Inv. Map I-210 B, scale 1:500,000, 1958.

604 Geographic map of the Tihamat Ash Sham quadrangle, Kingdom of Saudi Arabia, by G. F. Brown and R. O. Jackson: U.S. Geol. Survey Misc. Geol. Inv. Map I-216 B, scale 1:500,000, 1958. 
Rel. No.

605 Geographic map of the western Persian Gulf quadrangle, Kingdom of Saudi Arabia, by Max Steineke, T. F. Harriss, K. R. Parsons, and E. L. Elberg: U.S. Geol. Survey Misc. Geol. Inv. Map I-208 B, scale 1:500,000, 1958.

606 Geologic map of the northern Tuwayq quadrangle, Kingdom of Saudi Arabia, by R. A. Bramkamp and L. F. Ramirez: U.S. Geol. Survey Misc. Geol. Inv. Map I-207 A, scale 1:500,000, 1958.

607 Geologic map of the Tihamat Ash Sham quadrangle, Kingdom of Saudi Arabia, by G. F. Brown and R. O. Jackson: U.S. Geol. Survey Misc. Geol. Inv. Map I-216 A, scale 1:500,000, 1958.

608 Geologic map of the western Persian Gulf quadrangle, Kingdom of Saudi Arabia, by Max Steineke, T. F. Harriss, K. R. Parsons, and E. L. Elberg: U.S. Geol. Survey Misc. Geol. Inv. Map I-208 A, scale 1:500,000, 1958.

609 Geographic map of the central Persian Gulf quadrangle, Kingdom of Saudi Arabia, by R. A. Bramkamp and L. F. Ramirez: U.S. Geol. Survey Misc. Geol. Inv. Map I-209 B, scale 1:500,000, 1959.

610 Geographic map of the northeastern Hijaz quadrangle, Kingdom of Saudi Arabia, by G. F. Brown and R. O. Jackson: U.S. Geol. Survey Misc. Geol. Inv. Map I-205 B, scale 1:500,000, 1959.

611 Geographic map of the northeastern Rub' al Khali quadrangle, Kingdom of Saudi Arabia, by R. A. Bramkamp and L. F. Ramirez: U.S. Geol. Survey Misc. Geol. Inv. Map I-214 B, scale 1:500,000, 1959.

612 Geographic map of the northwestern Hijaz quadrangle, Kingdom of Saudi Arabia, by G. F. Brown, R. O. Jackson, and R. G. Bogue: U.S. Geol. Survey Misc. Geol. Inv. Map I-204 B, scale 1:500,000, 1959.

613 Geographic map of the northwestern Rub' al Khali quadrangle, Kingdom of Saudi Arabia, by R. A. Bramkamp and L. F. Ramirez: U.S. Geol. Survey Misc. Geol. Inv. Map I-213 B, scale 1:500,000, 1959.

614 Geographic map of the Wadi al Batin quadrangle, Kingdom of Saudi Arabia, by R. A. Bramkamp and L. F. Ramirez: U.S. Geol. Survey Misc. Geol. Inv. Map I-203 B, scale 1:500,000, 1959.

615 Geologic map of the Asir quadrangle, Kingdom of Saudi Arabia, by G. F. Brown and R. O. Jackson: U.S. Geol. Survey Misc. Geol. Inv. Map I-217 A, scale 1:500,000, 1959.

616 Geologic map of the northwestern Rub' al Khali quadrangle, Kingdom of Saudi Arabia, by R. A. Bramkamp and L. F. Ramirez: U.S. Geol. Survey Misc. Geol. Inv. Map I-213 A, scale 1:500,000, 1959.

617 Geologic map of the Wadi al Batin quadrangle, Kingdom of Saudi Arabia, by R. A. Bramkamp and L. F. Ramirez: U.S. Geol. Survey Misc. Geol. Inv. Map I-203 A, scale 1:500,000, 1959.

618 The Arabian Shield, by G. F. Brown and R. O. Jackson, pt. 9 of Precambrian stratigraphy and correlations: Internat. Geol. Cong., 21st, Copenhagen 1960, Rept., p. 69-77, 1960.

619 Distribution of ages in the Arabian segment of the African Shield [abs.], by G. F. Brown and L. T. Aldrich: Geol. Soc. America Bull., v. 71, no. 12, pt. 2, p. 1813, 1960.

620 Geographic map of the Darb Zubaydah quadrangle, Kingdom of Saudi Arabia, by R. A. Bramkamp and L. F. Ramirez: U.S. Geol. Survey Misc. Geol. Inv. Map I-202 B, scale 1:500,000, 1960.

621 Geomorphology of western and central Saudi Arabia, by G. F. Brown, pt. 21 of Other subjects: Internat. Geol. Cong., 21st, Copenhagen 1960, Rept., p. 150-159, 1960. 
Ref. No.

622 Dating desert ground water, by Leland Thatcher, Meyer Rubin, and G. F. Brown: Science, v. 134, no. 3472, p. 105-106, 1961.

623 Geographic map of the Jawf-Sakakah quadrangle, Kingdom of Saudi Arabia, by R. A. Bramkamp and L. F. Ramirez: U.S. Geol. Survey Misc. Geol. Inv. Map I-201 B, scale 1:500,000, 1961.

624 Geographic map of the Wadi ar Rimah quadrangle, Kingdom of Saudi Arabia, by R. A. Bramkamp, L. F. Ramirez, and G. F. Brown: U.S. Geol. Survey Misc. Geol. Inv. Map I-206 B, scale 1:500,000, 1961.

625 Geologic map of the central Persian Gulf quadrangle, Kingdom of Saudi Arabia, by R. A. Bramkamp and L. F. Ramirez: U.S. Geol. Survey Misc. Geol. Inv. Map I-209 A, scale 1:500,000, 1961.

626 Geologic map of the northeastern Rub' al Khali quadrangle, Kingdom of Saudi Arabia, by R. A. Bramkamp and L. F. Ramirez: U.S. Geol. Survey Misc. Geol. Inv. Map I-214 A, scale 1:500,000, 1961.

627 Geographic map of the eastern Rub' al Khali quadrangle, Kingdom of Saudi Arabia, by E. L. Elberg, R. D. Gierhart, and L. F. Ramirez: U.S. Geol. Survey Misc. Geol. Inv. Map I-215 B, scale 1:500,000, 1962.

628 Geographic map of the south central Rub' al Khali quadrangle, Kingdom of Saudi Arabia, by L. F. Ramirez, E. L. Elberg, and H. H. Helley: U.S. Geol. Survey Misc. Geol. Inv. Map I-219 B, scale 1:500,000, 1962.

629 Geographic map of the southeastern Rub' al Khali quadrangle, Kingdom of Saudi Arabia, by L. F. Ramirez, E. L. Elberg, and H. H. Helley: U.S. Geol. Survey Misc. Geol. Inv. Map I-220 B, scale 1:500,000, 1962.

630 Geographic map of the southern Najd quadrangle, Kingdom of Saudi Arabia, by R. O. Jackson, R. G. Bogue, G. F. Brown, and R. D. Gierhart: U.S. Geol. Survey Misc. Geol. Inv. Map I-211 B, scale 1:500,000, 1962.

631 Geographic map of the Wadi as Sirhan quadrangle, Kingdom of Saudi Arabia, by R. A. Bramkamp, G. F. Brown, D. A. Holm, and N. M. Layne, Jr.: U.S. Geol. Survey Geol. Inv. Map I-200 B, scale 1:500,000, 1962.

632 Geographic map of the western Rub' al Khali quadrangle, Kingdom of Saudi Arabia, by R. A. Bramkamp, R. D. Gierhart, L. D. Owens, and L. F. Ramirez: U.S. Geol. Inv. Map I-218 B, scale 1:500,000, 1962.

633 Geographic map of the Arabian Peninsula, Kingdom of Saudi Arabia (revised), by G. F. Brown and others: U.S. Geol. Survey Misc. Geol. Inv. Map I-270 B-2, scale 1:2,000,000, 1963.

634 Geologic map of the Arabian Peninsula, Kingdom of Saudi Arabia, by G. F. Brown and others: U.S. Geol. Survey Mise. Geol. Inv. Map I-270 A, scale $1: 2,000,000,1963$.

635 Geologic map of the Darb Zubaydah quadrangle, Kingdom of Saudi Arabia, by R. A. Bramkamp and L. F. Ramirez: U.S. Geol. Survey Misc. Geol. Inv. Map I-202 A, scale 1:500,000, 1963.

636 Geologic map of the eastern Rub' al Khali quadrangle, Kingdom of Saudi Arabia, by E. L. Elberg, R. D. Gierhart, and L. F. Ramirez: U.S. Geol. Survey Misc. Geol. Inv. Map I-215 A, scale 1:500,000, 1963.

637 Geologic map of the Jawf-Sakakah quadrangle, Kingdom of Saudi Arabia, by R. A. Bramkamp, L. F. Ramirez, Max Steineke, and W. H. Reiss: U.S. Geol. Survey Misc. Geol. Inv. Map I-201 A, scale 1:500,000, 1963.

638 Geologic map of the northeastern Hijaz quadrangle, Kingdom of Saudi Arabia, by G. F. Brown, N. M. Layne, Jr., G. H. Goudarzi, and W. H. Maclean: U.S. Geol. Survey Misc. Geol. Inv. Map I-205 A, scale 1:500,000, 1963 . 
Ref. No.

639 Geologic map of the northwestern Hijaz quadrangle, Kingdom of Saudi Arabia, by G. F. Brown, R. O. Jackson, R. G. Bogue, and E. L. Elberg: U.S. Geol. Survey Misc. Geol. Inv. Map I-204 A, scale 1:500,000, 1963.

640 Geologic map of the south central Rub' al Khali quadrangle, Kingdom of Saudi Arabia, by L. F. Ramirez, E. L. Elberg, and H. H. Helley: U.S. Geol. Survey Misc. Geol. Inv. Map I-219 A, scale 1:500,000, 1963.

641 Geologic map of the southeastern Rub' al Khali quadrangle, Kingdom of Saudi Arabia, by L. F. Ramirez, E. L. Elberg, and H. H. Helley: U.S. Geol. Survey Geol. Inv. Map I-220 A, scale 1:500,000, 1963.

642 Geologic map of the southern Hijaz quadrangle, Kingdom of Saudi Arabia, by G. F. Brown, R. O. Jackson, R. G. Bogue, and W. H. Maclean: U.S. Geol. Survey Misc. Geol. Inv. Map I-210 A, scale 1:500,000, 1963.

643 Geologic map of the southern Najd quadrangle, Kingdom of Saudi Arabia, by R. O. Jackson, R. G. Bogue, G. F. Brown, and R. D. Gierhart: U.S. Geol. Survey Misc. Geol. Inv. Map I-211 A, scale 1:500,000, 1963.

644 Geologic map of the Wadi ar Rimah quadrangle, Kingdom of Saudi Arabia, by R. A. Bramkamp, L. F. Ramirez, G. F. Brown, and A. E. Pocock: U.S. Geol. Survey Misc. Geol. Inv. Map I-206 A, scale 1:500,000, 1963.

645 Geologic map of the Wadi as Sirhan quadrangle, Kingdom of Saudi Arabia, by R. A. Bramkamp, G. F. Brown, D. A. Holm, and N. M. Layne, Jr.: U.S. Geol. Survey Misc. Geol. Inv. Map I-200 A, scale 1:500,000, 1963.

646 Geologic map of the western Rub' al Khali quadrangle, Kingdom of Saudi Arabia, by R. A. Bramkamp, R. D. Gierhart, L. D. Owens, and L. F. Ramirez: U.S. Geol. Survey Misc. Geol. Inv. Map I-218 A, scale 1:500,000, 1963.

\section{SOUTHERN RHODESIA}

647 Ground water in the Sabi Valley, Southern Rhodesia, by P. E. Dennis: In U.S. Geol. Survey Prof. Paper 424-D, p. D231-D234, 1961.

\section{SUDAN}

648 Availability of ground water in Kordofan Province, Sudan, by H. G. Rodis: Sudan Geol. Survey Bull. 12, 16 p., 1963.

649 Ground water in the Nahud outlier of the Nubian Series, Kordofan Province, Sudan, by H. G. Rodis and Wilson Iskander: In U.S. Geol. Survey Prof. Paper 475-B, p. B179-B181, 1963.

\section{TAIWAN}

650 Differential thermal curves of minerals from Taiwan, by Samuel Rosenblum and P. H. H. Lu: Geol. Soc. China Proc., no. 2, p. 147-151, 1959.

651 Mineral exploration in Taiwan, 1959, by Samuel Rosenblum: Taiwan Mining Industry, v. 1-2, p. 1-5, 1960.

652 Potassium-argon ages of micas from the Tananao schist terrane of Taiwana preliminary report, by T. P. Yen and Samuel Rosenblum: Geol. Soc. China Proc., no. 7, p. 80-81, 1964.

\section{THAILAND}

653 Geologic reconnaissance of the mineral deposits of Thailand, by G. F. Brown, Saman Buravas, Jumchet Charaljavanaphet, Nitipat Jalichandra, W. D. Johnston, Jr., Vija Sresthaputra, and G. C. Taylor, Jr.: U.S. Geol. Survey Bull. 984, 183 p., 20 pls., 38 figs., 1951 [1952]; [in Thai] Royal Thai Geol. Survey Bull. 1, 1951. 
Ref. No.

654 Reconnaissance of the geology and ground water of the Khorat Plateau, Thailand, by P. E. LaMoreaux: U.S. Geol. Survey Water-Supply Paper 1429, 62 p., 9 pls., 11 figs., 1958.

655 Integrated mineral exploration at Phu Hin Lek Fai Loei-Chiengkarn area, Thailand, by H. S. Jacobson: Econ. Comm. Asia and Far East, Seminar Geochem. Prosp. Methods and Techniques, Bangkok 1963, Seminar Paper 5, p. 175-177, 1963.

\section{TUNISIA}

656 Hydrogeology of the Zarzia area, Tunisia, by R. C. Vorhis: U.S. Geol. Survey open-file report, 20 p., 1 fig., 1959.

657 Ground-water dilemma at Téboulba, Tunisia, by H. E. Thomas and L. C. Dutcher: Internat. Assoc. Sci. Hydrology Pub. 57, v. 2, p. 597-606, 1961.

658 Programme proposé pour l'exécution de sondages de reconnaissance dans le Sahel de Sousse et les basses steppes, Tunisie, by L. C. Dutcher and M. S. Mahjoub: Tunisia Secretariat Etat a Agriculture, Groupe Hydraulique et Equipement Rural, 31 p., 5 pls., 1962.

659 Project analysis for the water resources development project for drilling fifty water wells in Tunisia, by L. C. Dutcher: Tunisia Secretariat Etat à Agriculture, Groupe Hydraulique et Equipement Rural, 42 p., 9 supp., 1962.

660 Tables de renseignements se rapportant aux puits creuses à la main et aux sondages et forages de la région de Téboulba, Tunisie, by L. C. Dutcher, M. S. Mahjoub, and others: Tunisia Secretariat Etat à Agriculture, Groupe Hydraulique et Equipement Rural, 61 p., 2 figs., 1962.

661 La venue de l'eau souterrraine dans la région de Téboulba, Tunisie, sa qualité chimique et son utilisation, by L. C. Dutcher, H. E. Thomas, and M. S. Mahjoub: Tunisia Secretariat Etat à Agriculture, Groupe $\mathrm{Hy}-$ draulique et Equipement Rural, 66 p., 12 figs., 1962.

662 Hydrologie de la région du Sahel de Sousse, by L. C. Dutcher and H. E. Thomas: Tunisia Secretariat Etat à Agriculture, Groupe Hydraulique et Equipement Rural, 265 p., 31 figs., 1963.

663 Table des coupes du sondeur des forages executés dans la région du Sahel de Sousse, Tunisie, by L. C. Dutcher and M. S. Mahjoub: Tunisia Secretariat Etat a Agriculture, Groupe Hydraulique et Equipement Rural, 130 p., 3 figs., 1963.

664 Tables de renseignements se rapportant aux sondages, forages, puits et à la pluviometrie de la région du Sahel de Sousse, Tunisie, by L. C. Dutcher and M. S. Mahjoub: Tunisia Secretariat Etat à Agriculture, Groupe Hydraulique et Equipement Rural, 229 p., 7 figs., 1963.

\section{TURKEY}

665 Effect of sediment on ancient cities of the Aegean Coast, Turkey, by L. J. Snell: Internat. Assoc. Sci. Hydrology Bull., v. 8, no. A, p. 71-73, 2 figs., 1963.

666 Exploration for phosphorite in Turkey-a case history, by R. P. Sheldon: Econ. Geology, v. 59, no. 6, p. 1159-1175, 1964.

\section{URUGUAY}

667 Reconnaissance of phosphate deposits near Minas, Uruguay, by E. B. Eckel and Charles Milton: Econ. Geology, v. 48, no. 7, p. 437-446, 1953. 
Ref. No.

\section{VENEZUELA}

668 Geología de la región de los Teques-Cúa, Venezuela, by R. J. Smith: Venezuela Dirección Geología Bol. Geología, v. 2, no. 6, p. 333-406, 1952; Geol. Soc. America Bull., v. 64, no. 1, p. 41-67, 1953.

\section{WEST INDIES}

669 Pumice and pozzalan deposits in the Lesser Antilles, by E. B. Eckel: U.S. Geol. Survey open-file report, 56 p., 22 p. app., 1960.

670 Probe West Indies for volcanic raw materials, by E. B. Eckel: Rock Products, v. 65, no. 2, p. 108-113, 5 figs., 1962. 



\section{INDEXES}

\section{AUTHOR INDEX}

A

Abad, L. F

Abbas, S. H

Abele C., Guillermo

Adyalkar, P.

Aguirre, Luis

Albear, J. F. de

Aldrich, L. T

Ali, S. T

Aliste T., Nelson

Almeida, S. C. de

Andrews, D. A

Antonio, I. S

Asad, S. A.

Ashley, B. E

Asrarullah

Assad, J. C

Axelrod, J. M

Ayers, F. M.

$472,474,480,481,490$

464-466 488

158

324

316,317

B

Baldwin, E. M

319

Baranovsky, Salomón

214

Barbosa, A. L. M 23 , $29,30,32,56,58,61,63,67,149$

Barnes, Harley 570 , $576,577,587,590$

Barraza S., Lorenzo 190

Behre, C. H., Jr 393

Bellido B., Eleodoro 515 , $516,520,523$

Bennett, G. D 485

Bergquist, H. R 263,275

Bertaiola, Mario $332,334,335$

Black, R. F 452,456

Bodenlos, A. Im 44,45 , $55,73,432,437,508,519,521$ Bogue, R. G. $469,470,475-$ $477,487,612,630,639,642,643$

Bowes, William 231

Bradley, Edward 315

Brambilla, Dante
Rer. No. Bramkamp, R. A $\ldots 59$,
$598-600,606,609,611,613,614$, $616,617,620,623-626,631,632$, $635,637,644-646$.

Bravo S., Nelson.............. 231

Brigham, R. H........... 10

Brill, K. G., Jr... . . . . . . . 319

Brown, G. F . . . . . 596-599, 601-604, 607, 610, 612, $615,618,619,621,622,624,630$, $631,633,634,638,639,642-645$, 653.

Brown, G. W . . . 6

Brown, R. W ........ 64

Buravas, Saman_............. 653

Burbank, W. S _............ 274

Butler, A. P., Jr............. 322

Butler, R. D_............. 35,39

Calkins, J. A _............ 493

Cárdenas, Salvador

Carron, M. K. . . . . . . _ _. 324

Carter, W. D _.. 193, 201, 208, 234, 242

Casertano, Lorenzo . . . . . . . . 224

Castillo U., Octavio _ 220, 236, 240, 244

Cederstrom, D. J._...... 158, 332, 334

Chakravarty, S. C._._..... 291

Charaljavanaphet, Jumchet..... 653

Cheong, Chang Hi........... 318

Clarke, F. E _....... 267, 268, 270

Coelho, I. S _. _ . . .

Conant, L. C _ _. _ _ _ _ 269, 351

Conybeare, C. E. B...... _._ 272, 273

Cooper, W. G. G.......... 466

Corvalán, José. ......... 195, 202, 204

Cox, M. W. . . . .

Crispin, O. A _ _ 560, 568, 572, 574, 593

Cruz, D. P _ _ _ _ _ _ _ _ _ 5 545, 551

Cruz, Juan de la ............ 570

Cruz, Miguel de la........... 584

Cserna, Zoltán de _........... 425,

$450,451,453,455,457$ 
D

Danilchik, Walter

Daviess, S. N

Davis, W. E

Deghaies, Fituri

Dennis, P. E

Dequech, Victor

Dingman, R. J. $209,210,219,222,225,230,233$, $240,245,321$.

Dobrovolny, Ernest_ 12-15, 205, 231

Donoso, R., Jaime

Dorr, John Van N., 2d ......... 1, 4, $28,42,46,49-53,57,60,61,63$, $69,72,77,78,83,84,90,94,97$, $98,100,101,108,111,118,124$, $149,151,160,162$.

Douglass, R. C

Doyel, W. W

200 $232,236,239,240,321,328,330,354$

Dunkle, D. H. $415,479,491$

Dutcher, L. C _ . _ . _ _ _ 6 657-664 Dutra, C. V. $104,125,154,163$

\section{$\mathbf{E}$}

Eakin, T. E

$5,290,311$

Eckel, E. B._._ 497-500, 667, 669, 670

Edwards, J. D _............. 417

Elberg, E. L._._. $608,627-629,636,639-641$
Ericksen, G. E._. $214,216,223,227,241,503,504$, 508, 511, 514, 527.

\section{$\mathbf{F}$}

Fahey, J. J.

Fairbairn, H. W

$43,48,54$

Falcón M., Eduardo_... _ 220, 232, 244

Fatmi, A. N.

479

Fernandez C., Jaime_........ _ 501, 504

Fernandez, N. S_._._. _... _. 533 ,

580, 584, 588, 589, 592

Flint, D. E.

Flores W., Hector

Fontanos, C. A. . . . . _ _ _ 588, 592

Foshag, W. F_..._. $355,364,419$

Francisco, F. U.......... 573

Frayha, Resk........... 31, 38, 56

Fries, Carl, Jr....... $360,375,384,388,389,391$, $393,395,396,400-403,412,413$, $415,420-422,444,452,456$.
G

Ref. No.

Gair, J. E__._. _..... 84, 87, 109, 141

Gallagher, David.............. 320 ,

$365-367,382,405$

Galli O., Carlos_........ 210, 224, 229

Ganeshan, K_............. 298

García R., Antonio ........... 458

Gardner, L. S.

Garrett, A. A . . . . . . . . . . 295

Geyne, A. R........ 408, 452, 456

Ghosh, P. K............. 302

Gibson, Russell .............. 307

Gierhart, R. D........... 598, 599,

$627,630,632,636,643,646$

Goddard, E. N............. 274

Goldich, S. S__ _._. _._. _ 263, 275

Gonzáles, E. M. ............ 11

Gonzales, M. L. . _ _ _.

González-Reyna, Jenaro_. . . . . . 364,

368,419

Gordon, Mackenzie, Jr_-_._ 40, 64, 264

Goudarzi, G. H........... 329,

$340-343,345,351,638$

Greeman, D. W._._.

Gualtieri, J. L. . . . . . . . 337

Guerra P., Felipe_._.

Guild, P. W ........... 46, 50,

$61-63,66,71,81,255-257$

Guiza, Reinaldo, Jr...... 372, 390, 398

Gutiérrez, Celedonio_......... 369, $379,395,396,400-403,413$

H

Haddar, Yousef ............. 346

Harbour, R. L_. _............ 489

Hardison, C. H . . . . . . . . . 311

Harrington, J. F _. . . . . . 247, 248, 593

Harriss, T. F _. _......... 605, 608

Hawkes, H. E............ 463

Haynes, D. D.............. 82, 85, $105-107,136,159$

Heckmiller, I. A._._......... 9

Helley, H. H _. _... 628, 629, 640, 641

Hemphill, W. R............. 482

Henriquez, Hugo_............. 237

Hernández O., David.......... 359

Hernández, J. P

Herz, Norman . ...... 96, 99, 104, 125, $128,134,139,143,154,163$

Hibbard, C. W ...

Holm, D. A._........... 631, 645

Holt, D. N . . . . . . . . . . . 464

Horen, Arthur. .............. 77 
Ref. No.

Ref. No.

Houston, J. R

404 Lemke, Richard.

$205,229,231$

Hoy, N. D

Lemoine, R. C_- 277-279, 281, 283-285

Hubach, Enrique

Leonardos, O. $\mathrm{H}$

Hulin, C. D

Lewis, G. E 259,265

Hurley, P. M

Lewis, R. W., Jr

505 ,

Ibañez, C. B._. I

Iberico M., Mariano.

Idris, $\mathrm{H}$

Ingerson, Earl

Irving, E. M 170,303 , 529-548, 550-559, 561, 563-567, $581-583,594$.

Iskander, Wilson.

\section{$\mathrm{J}$}

Jackson, R. O_598, 599, 602-604, 607, $610,612,615,618,630,639,642$, 643.

Jackson, W. H

260,262

Jacobson, H. S

655

Jalichandra, Nitipat

653

Johnson, R. F . . . . . . .

$142,304,506,507,510$

Johnston, W. D., Jr_- 2, 3, 8, 16-22, 24-27, 33-36, 39, 47, 70, 76, 127, $152,653$.

Jones, J. R _ _. _ _ _ 331, 349, 350, 353 Jones, P. H._._- 186, 188, 189, 294, 300 Jongco, C. P

576

Kent, B. H....... $440-442,450,458$

Kent, D. F

501

Khan, M. Y

489

Khan, N. M

483

Kidwai, A. H

482

Kidwai, Z. U

Kiilsgaard, T. $\mathrm{H}$

King, P. B

373

Kinkel, A. R., Jr._._. 573-575, 578 Klepper, M. R_-- $30,37,38,41,56,320$ Klinger, F. L_ _............ _ 473, 484 Koschmann, A. H........... 264

Krauskopf, K. B._... _ $362,383,387$

Krishnaswamy, S............. 292

LaMoreaux, P. E

L

Larrabee, D. M.

Larralde, Amadeo

$30,31,41,56,394$

Layne, N. M., Jr

Lazaga, G. C

$631,638,645$

576

Lindberg, M. L

$507,512,513,528$

Lohman, K. E

López C., Jaime

Lu, P. H. H $67,68,74,103$

230

248

650

M

McAllister, J. F_ 171, 181, 187, 254, 359

Maclean, W. H. . . . . . . . . . 638, 642

Maguire, F. J _... _._. _ _ _ _ 328, 354

Mahjoub, M. S_ $658,660,661,663,664$

Manrique P., Alberto ......... 510

Mapes V., Eduardo_.... _. . _ _ 430, 431

Matzko, J. J _... _. _ _ _ _ _ _ 136, 488

Mau, Henry ................ 105, 106

Maxwell, C. H._. _... _... _ _ 89, 131

Mazo, Ricardo .............. 497

Meave T., Eduardo _. . . . . . . 418

Mehech, Sonia _._. 197

Melendres, M. M., Jr _. _ _.... 587

Mello, Neuza M. P. de........ 116

Meyerhoff, H. A. .

Milton, Charles_ $324,404,498,500,667$

Mitra, A_. . . . . . . 301

Moore, S. L. . .

Moraga B., Aldo........... 232, 238

Morel, S. W _... . . _ _ _ _ 464

Morris, R. H. . . . . . . . . 147

Myers, A. T_.

\section{$\mathbf{N}$}

Narayanaswami, S_._._. . . . 291

Narváez L., Sigfredo_....... _ . 505, 516

Newhouse, W. H. .

Newport, T. G.......... 346

Uca, Generoso _............. 542

Offield, T. W . _. . . . . . . . 493

Ogilbee, William _........... 338,

$339,344,347,348,352$

Ojeda R., Jesús_439, 451, 453, 455, 457

Olive, W. W .............. 524

O'Rourke, J. E._._........ 110

Overstreet, W. C........... 320

Owens, L. D._.

Oza, M. M._.......... 287, 301 
$\mathbf{P}$

Page, L. R

Paiva, Glycon de.

Palacio, D. N

Pares, M. da S.

Park, C. F., Jr ... 49, 59, 61, 251, 253

Parker, R. L _... . . . . . . . . . 191, 226

Parsons, K. R.............. 605, 608

Pathak, B. D_............ 288, 299

Pecora, W. T $-23,29,32,41,43,48$,

$54,56,58,67,68,74,103$

Peoples, J. W _. . . _ _ . . _ 584, 588, 589

Perez, Ernesto . . . . . . . . . . . . . . 193

Perez L., José. . . . . . . . . . . . . . . 458

Perez R., Gabriel _... . . . . . . _. 226

Pérez S., Rafael . . . . . . . . 364-367, 382

Pesquera V., Rubén. . . . . . . . . 427

Petersen B., Ulrich . . . . . . . . . . 511

Pierson, C. T . . . . . . . 8 82, 85, 107, 137

Pilac, J. E_... . _ _ . . . . . . . 576, 593

Pinson, W. H. . . . . . . . . . . . 128

Pizarro A., Bernardo........... . 223

Pocock, A. E _. . . . . . . . . . . . . 644

Pomerene, J. B . . . . . . . . . . . . 69,

$84,88,91,112,120,155,593$

Prescott, G. C _. . . . . . _ _ _ 312, 313

Probert, Alan . . . . . . . . . . . 456

Quema, J. C.............. 535, 546

$\mathbf{R}$

Rahman, Habib-ur. . . . . . . . 491

Ramirez, L. F . . . . . . . . 600, $606,609,611,613,614,616,617$, 620, 623-629, 632, 635-637, 640, 641, 644, 646 .

Reeves, R. G_........ 129, 130, 133

Reinemund, J. A....... 319, 483, 484

Reiss, W. H............... 637

Ribeiro, F. E. . . . . . . . 82

Richter, D. H _. . . . . _ _ 260, 262

Robeck, R. C_............. 411, 427

Roberts, R. J._.......... 170, 249

Robertson, J. F............ 148

Rocha, V. S _.

$386,416,434,435,438$

Rodis, H. G . . . . . . . . . . . 648, 649

Rodríquez C., José. . . . . . . . 385

Rogers, C. L............... 406, $407,410,425,451,453,455,457$

Rose, H. J., Jr......... . 195, 202, 204 Rosenblum, Samuel

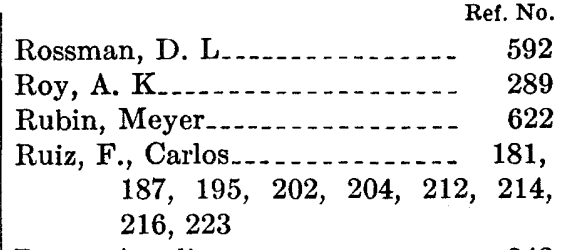

Russo. Aurelio . . . . . . . . . . . 348

Rynearson, G. A. . . _ 6 69, 84, 92, 119

s

Saint-Amand, Pierre _. . . . . . . . 241

Salas O., Raul_............. 226

Sallention, Brigitte_._._._._. 116

Samaniego, Sisenando _........ $573-$

$575,578,584$

Sample, R. D.......... 320

Sanchez M., S. H. . . _ . . _... 458

Santos, Victor de los_......... 571

Santos-Yñigo, Luis _ . _ _ _ 573, 574, 577

Sayán M., J. L. _. . _ _ _ 522, 525, 526

Sayre, A. N _. . . . . _ _ _. 2 271, 460

Schmidt, R. G........... 469,

$472,474,480,481,490$

Schmitter, Eduardo_._._. _. _ 360,389

Schneider, Robert_. _. . . 150, 309, 310

Schoechle, G. L. . . . . . . . . . . 6, 7

Schoff, S. L_._. $461,462,522,525,526$

Scorza, E. P........... 16

Segerstrom, Kenneth . . . . . . . . 191, $192,194-199,202-204,206,211-$ $213,215,217,218,221,224$, $228,235,237,238,243,244$, $369,397,398,423,429,443$, $445-448,452,456$.

Sen, B. N _ _ _ _ _ _ _ 28 301

Sett, D. N _... . _ _ _ _ _ 289

Shainin, V. E_......... 171, 177-179

Sheldon, R. P............ 666

Shoup O., Samuel _......... 377

Shukla, K. D ............. 291

Silgado, Enrique _.......... 504

Simmons, G. C...... 93,

$100,126,131,146,157$

Simons, F. S _. _...... 170, 261, 409, $430,431,503,509,515-518,520$

Singewald, Q. D._._...... 246

Smith, R. J.

Smith, R. L_ _. . . . _ _... 409

Smith, W. C_............. 11, 398

Snell, L. J.... . . . .

Sohn, I. G

Sorem, R. K......... $579,580,591$ 
Stuart, W. T.

Subramanyam, M. R........ 291

Subramanyam, V.......... _ 294, 300

Sukamito, Rab.

Sulsona, P. T.

500

Swarzenski, W. V. . . . . _... 485, 492

Switzer, George.

\section{$\mathbf{T}$}

Tahirkheli, R. A. K. ........

Tarhuni, Hadi Ali.

Tavera A., Eugenio. $407,410,425,451,453,455,457$

Taylor, G. C., Jr _. . . . . . . 172-176, $180,182-185,271,276-289,293$, $296,299,301,302,459,495,653$

Teichert, Curt 491

Terrazas, Alfredo............. 404

Teves, J. S . . . . . . . . . . . . . . 5 531, 534

Thatcher, Leland............... 622

Thayer, T. P _..._. 250, 256, 322-325

Thomas, H. E.

$221,231,657,661,662$

Thompson, T. F _...... 496

Tibbitts, G. C., Jr ........... 327

Tileston, F. M............ 349

Tilling, R. I.............. 221

Tolbert, G. E_... 95, 113, 145, 153, 156 Trask, P. D _..._._ 356, 357, 385, 502

$\mathrm{U}$

Ulloa A., Salvador._._. _..._. 406 , $407,410,425,427$

Valenzuela, B. L. de_......... 197

Valenzuela M., Manuel ...... 220

Van Alstine, R. E van Vloten, Roger........... 451 , $453,455,457,478$

Vasconcelos, F. M. de___._. 19, 27, 36

Vemban, N. A._.......... 291

Venkatesh, V . . . ............ 291

Vergara, J. F _ _ 562, 568, 569, 585, 586

Versey, H. R _............ _. 312, 313

Veytia, Mario_.............. 392

Victorio, Visitacion. . . . . . . 589

Vita-Finzi, C. . . . .

Vlisidis, A. C. ............. 409

Vokes, H. E_................ 576

Vorhis, R. C_... 336, 338, 347, 348, 656

$\mathrm{W}$

Waite, H. A _... 266

Waldron, H. H............. 305, 306

Wallace, R. M_- 102, 116, 117, 121-123

Webber, B. N_........ 164-167, 439

Wedow, Helmuth _. . . . . . . 132, 138

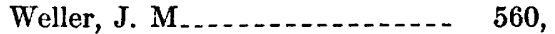

$562,568,569,571,572$

Whitcomb, H. A _......... 326

White, D. E. .......

$368,372,374,380,390$

White, M. G _. . _. $79,86,105,107,114,115,135$, $137,144,161,484,488$

Whitehead, Gilbert. ........... 57

Wiese, J. H............. 361

Wilcox, R. E. . . . . . . . . ... 370 ,

$371,376-379,414$

Williams, Howel . . . . . . . . . 362, 399

Wilson, B. W.............. 418

Wilson, I. F . . . . . $381,386,392,404,408,416,424$, $426,428,433-436,438,452,456$

Woodring, W. P........ 252, 494, 496

Worts, G. F., Jr_....... 168, 169, 595

$\mathrm{Y}$

Yates, R. G. . . . . . . 501

Yen, T. P........ 652

z

449, 454 $\mid$ Zepeda, Z. C................ 


\section{SUBJECT INDEX}

\begin{tabular}{|c|c|}
\hline Ref. No. & Ref. No. \\
\hline Anhydrite, Libya_. & Coal, Korea_. \\
\hline ntimony, Mexico & Mexico \\
\hline $368,372,380,390$ & Pakistan. \\
\hline real geology, Bolivia_...... 12,13,15 & Peru \\
\hline $\begin{array}{r}\text { Brazil__- } 52,81,97,115,116, \\
118,137,140,141,147,149,155\end{array}$ & $\begin{array}{l}\text { Philippines } \\
549,560,568-572,576,577,\end{array}$ \\
\hline$-\ldots-1$ & $585-587,590$. \\
\hline
\end{tabular}

Chile _._._. 180, $185,188,189,191,192,194$, 197-199, 210, 212, 213, 217, 221, $222,238,245$.

Cuba_ _. _. _. _ _ 252, 257, 259

Dominican Republic....... 264

India _........ _ 287, 288, 294, 299

Jamaica.................. 313

Kenya_. . . . . . . . . . . 316, 317

Korea_..._._._._._._._._. 321

Libya_................. 326

Mexico................ 365, $382,392,416,420-422,425-427$, $429-432,437,444,447,448,456$

Nyasaland............... 464-466

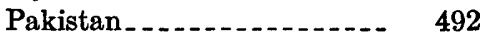

Panama................. 494

Paraguay

Peru._._._. 501, 507, 511-513, 520

Philippines_........... 535, $538,542,545,548,549,562,564$, 568-572, 576, 577, 579, 586, 587, 594.

Saudi Arabia......... 597, 618

Thailand............... 654

Venezuela_............... 668

See also Maps Geologic

Awards, honors, medals, Brazil_._ 127

Barite, Brazil........... 44

Pakistan . . . .

Bauxite, Dominican Republic... 263

Haiti_.................. 275

Bentonite, Pakistan._._._._._. 469

Book reviews, Egypt_........... 269

Calcite, Mexico_........_._. 384

Cartography, Mexico ........ 440-442

Caves, Brazil_............... 146

Celestite, Pakistan.

Chromite, Brazil _............ 17

Cuba_..... 250, 255, 257, 260, 262

Pakistan............... 475, 477

Philippines . . ............ 547,

Cobalt, Brazil_.............. 23

Copper, Brazil_.............. 80

Chile._........... 201, 208, 242

India_................. 297

Mexico_................ 416, 426

Peru.................... 513

Philippines_..... 551, 573-575, 578

Development of geological in-

stitutions, general _.......... 1-8

Brazil_._._._............ 152

Chile_..._._.

Diamonds, Brazil_............ 137

British Guiana_........ 167

Earthquakes, Chile_.......... 196, $205,224,231,232,241$

Peru._..._........ 504

Philippines_............. 534

Economic geology. See Mineral deposits.

Engineering geology, Chile _. _ 205, 229

Indonesia . . . . . . . . . . 305, 306

Philippines_........ 533, 536, 559

West Indies_........... _. 669, 670

See also Earthquakes, Landslides.

Fertilizers, Colombia........... 247

Fluorspar, Mexico_._._._. 364, 449, 454

Fuller's earth, Pakistan.......... 476

Geochemical prospecting, India _- 297 ,

Nigeria_... . . . . . . . . 463

Thailand._._._.

Geochemistry, Brazil_........ 95,

$104,125,139,154,163$

Philippines.

Taiwan_.............. 650

Geochronology, Brazil _ _ _ 25, 104, 128

Chile_. . .......... 195, 202, 204

Saudi Arabia_........... 618, 619

Taiwan............. 652

Geologic history, Libya. _..... 329

Philippines............. 555

$566,567,584,588,592 \mid$ Geologists, Philippines........ $\quad 529$ 
Ref. No. 196, 211, $224,225,228,235,237$

Mexico $393,397,443,445$

Peru. $502,503,517$

Philippines. $530,532,558$

Saudi Arabia

621

Geophysics, Cuba

260,262

Glaciology, Chile.

177

Gold, Brazil _..._ 87, 135, 145, 153, 156

British Guiana......... 165, 166

Chile

178

Gypsum, Libya

337

Heavy minerals, Philippines....

Hydrology, Afghanistan

Bolivia

593

9,10

Brazil 150,158

British Guiana

168,169

Chile.

$176,180,182-186,188-190$, $209,210,220,236,239,240,245$

Cuba

258

Egypt_. . . . . _. _. 26 266-268, 270

El Salvador . . . . . . . . . 271

Haiti . . . . . . . . . . . . 2 276-285

India _ _ 286-290, 293-296, 299-302

Israel

309,310

Jamaica

311-313

Jordan

315

Korea

321

Libya 326-

$328,330-336,338,339,344$, 346-348, 350, 352-354.

Nicaragua

459-462

Pakistan $485,486,492$

Panama 495

Peru $522,525,526$

Philippines

$536,556,595$

Saudi Arabia . . . _. . 596, 597, 622

Southern Rhodesia........ 647

Sudan 648,649

Thailand 654

Tunisia . . . . . . . . 656-664

Turkey 665

Iron, Brazil

28 ,

$50,53,57,59,60,62,63,66,69$, $71,72,78,81,83,84,88-94$, 96-102, 108-112, 116, 118-124, $126,129-131,133,134,139-141$, $143,146,149,151,155,160,162$ Liberia $322,323,325$

Libya.

Iron-Continued Ref. No.

Mexico................. 439

Pakistan . . . . . . . . . 471, 484

Peru._..._._.

Philippines . ........... 541, 543

Land reclamation, Libya...... $\quad 349$

Landslides, Bolivia. . . . -

Lead, Brazil_............... 142, 148

Chile................. 171

India................. 298

Nigeria.

Peru

$512,514,518,519,521,527,528$

Magnesite, Brazil_......... 45, 55, 73

Pakistan................ 478

Magnetite, Chile............ 179

See also Iron.

Manganese, Brazil_._._._... 23, 28,

$42,46,49,59,61,77,105,118$

British Guiana_.......... 164

Central America . . . . ...... 170

Costa Rica _............. 249

Cuba_.

Haiti_. _. . . . . . .

India _ . . . . . . . . . . 291, 292

Mexico $386,392,424,428,433-436,438$

Pakistan _. . . . . . . . . . . 487

Philippines _. _. 552, 579, 580, 591

Maps, geographic, Saudi Arabia_ 598, $600-605,609-614,620,623$, 624, 627-633.

geologic, Brazil_._._...... 117, $120-124,129,130,133$

Libya_._._.

Mexico_..._._._._. 373, 450

Paraguay

Peru

Philippines _. _. . . . 5 561, 581

Saudi Arabia _. 599, 606-608, $615-617,625,626,634-646$

See also Areal geology.

mineral, Chile _..._....... 214

topographic, Libya_....... 345

Mercury, Chile._._._._._._. 187

Colombia_.............. 248

Mexico_____ 359, 365-367, 382, 405

Peru__.__._._._._. 501

Philippines . . . . . . . . . . . 565

Metamorphism, Brazil _._ _ 99, 134, 143

Mica, Brazil__.__ 29-32, 38, 41, 56, 145

Mexico_._._._._._._._. 394 
Mineral deposits, geology Brazil Ref. No. $18,24,26,33,34,37,47,70$, $76,81,101,140,141,149,155$ Central America

Chile $207,214,216,226$

Colombia 246

Dominican Republic....... 264

Indonesia . . . . . . . . . . . . 303

Korea_._. . . . . . . . . . 320

Mexico

Pakistan _......... _ 468, 491, 493

Paraguay ............. 497, 500

Peru._. 505, 507, 513, 516, 520, 523

Philippines _........... 5 540, 557

Taiwan . . . . . . . . . . 651

Thailand _............. 653

West Indies _. . . . . . . . _ 6 669,670

See also individually indexed

economic minerals.

origin, Brazil__.__ $63,87,151,162$

Chile _. 178, 201, 207, 208, 215

Mexico

Peru

Philippines _. . . . . . . 58 58, 591

Mineralogy, Brazil_._ 43, 48, 51, 54, 58, $67,68,74,103,144,157$

Liberia

324

Mexico_............. 404, 409

Pakistan . . . . . . . . . 477

Peru................... 512

Mining geology, Brazil_...... 133, 156

British Guiana.......... 166

Iran . . . . . . . . . . . . . . 307

Mexico._._._._._._._. 428

Pakistan_. _. . . . _ _ _ 467, 489

Peru. . . . . . . . . . . . . 506

Philippines_........ 5 543, 544, 575

Nickel, Brazil.

Philippines

547

Paleobotany, Brazil

Paleontology, Chile

200,230

Israel 308

Mexico

415

Pakistan

479

Panama

Pegmatites, Brazil...........

$26,33,34,41,43,48,58$

Chile 494

16 ,

Petroleum, Jordan

Peru.

524

Philippines
Petrology, Brazil ........... _. 96, 126

Chile_................. 202

Cuba_................ 255

Ghana............... 272, 273

Mexico............. 374, 381, 414

Paraguay................ 498

Philippines_............ 589

Phosphate, Brazil . . . . . . . . . . 20

Indonesia_.............. 304

Mexico

$407,410,425,451,453$

Philippines_._._. 531, 546, 563, 582

Turkey _... _. _ _ _ _ _ _ 666

Uruguay _............... 667

Photogeology, Mexico_._ _ 440-442, 458

Pakistan_................. 482

Platinum, Philippines........... 547

Pyrite, Philippines_..._._._._. 551

Quaternary geology, Chile.... 243, 244

Quartz, Brazil_............. 21, 35, 39

Radioactive deposits, Brazil _... 82,

$105,106,132,138$

Pakistan_...... 472, 474, 480, 490

See also Thorium, Uranium.

Salt, Chile_................. 227

Libya_............ 340, 342, 343

Silver, Chile_................ 217

Mexico............. 430, 431, 452

Peru. . . . . . . . . . . . . 528

Philippines. . . . _. _. _. 544

Soils, Indonesia . . . . . . . . . . 306

Statistics, Philippines_......... 537

Stratigraphy, Brazil_....... 40, $69,84,88-94,98,100,102,108-$ $110,112,131$.

Chile._._...... 193, 202, 206, 234

Mexico_............... 381, $391,411,415,417,418,423,446$

Pakistan _... . . . . . . . . . . 491

Panama............... 496

Structural geology, Brazil_._. 65, 111

Chile........... 203, 218, 219, 233

Cuba_... . . . . . . . . . 255, 256

Mexico_........ 381, 423, 455, 457

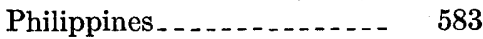

Submarine geology, Philippines _- $\quad 554$

Sulfur, Philippines_........... 550

Technical assistance program in

geology, Mexico.......... 388

Pakistan ... . . . . . . . . . 483, 488

555 Thorium, Brazil. . . . . . . . . . 144 
Ref. No.

Tin, Brazil 37.

Ref. No.

Mexico

$355,389,398$

Volcanism and volcanoes,

Trace elements, Brazil_........ 95

Tungsten, Argentina _........ 11

Brazil............ 19, 22, 27, 36

Chile.................. 181

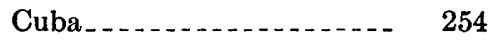

Mexico_... . . . . . _ 360, 361

Uranium, Brazil $\ldots . . . . . . . . . .-75$, $79,85,86,107,113,114,135$, 136, 144, 159, 161.

Pakistan. 468,481

Ecuador._.

Mexico _... . . . . . . . 356-358,

$362, \quad 369-371, \quad 376-379,387$, $395,396,399-403,412,413,419$

Zinc, Brazil_._......... 80, 142, 148

Chile._. . . .

India_.............. 298

Nigeria_...

Peru._._.

$512,514,518,519,521,527$, 528. 


